\title{
Klimaatrisico's en kansen in de open teelten
}

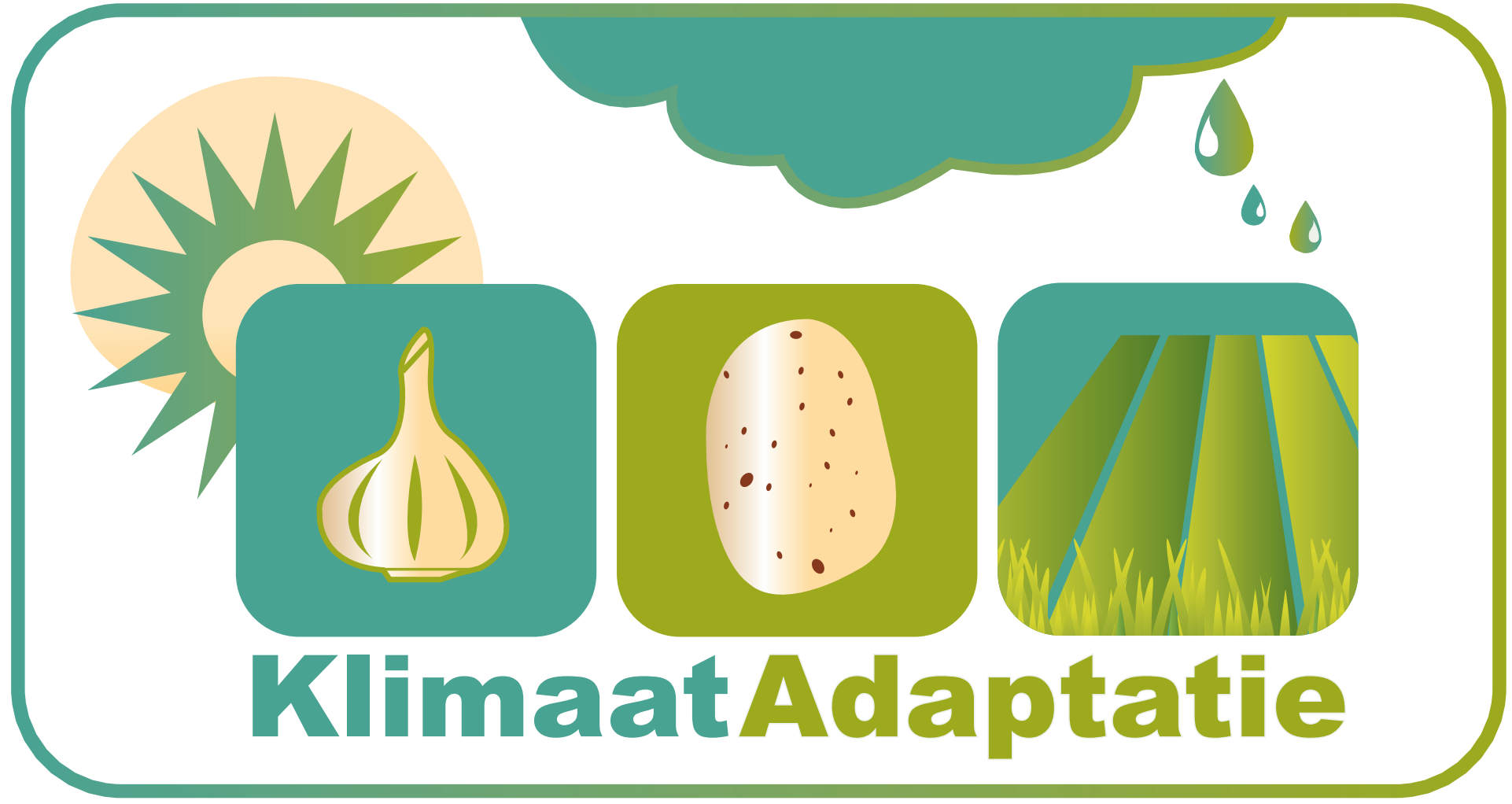

Daan Verstand, William Bijker, Daniel Simonse 


\title{
Klimaatrisico's en kansen in de open teelten
}

\author{
Daan Verstand \\ William Bijker
}

Daniel Simonse

Wageningen University \& Research

Dit onderzoek is uitgevoerd door de Stichting Wageningen Research (WR), business unit Open Teelten in het kader van de PPS Klimaatadaptatie Open Teelten (projectnummer TKI-LWV19148/BO-60-002-004).

WR is een onderdeel van Wageningen University \& Research, samenwerkingsverband tussen Wageningen University en de Stichting Wageningen Research.

Rapport WPR-902 
Verstand, D., Bijker, W., Simonse, D., 2021. Klimaatrisico's en kansen in de open teelten. Wageningen Research, Rapport WPR-902.

Dit rapport is gratis te downloaden op https://doi.org/10.18174/555534

Trefwoorden: Klimaatadaptatie, kwetsbaarheden, maatregelen.

(C) 2021 Wageningen, Stichting Wageningen Research, Wageningen Plant Research (WPR), Business unit Open Teelten, Postbus 430, 8200 AK Lelystad; www.wur.nl/plant-research.

KvK: 09098104 te Arnhem

VAT NL no. 8113.83.696.B07

Stichting Wageningen Research. Alle rechten voorbehouden. Niets uit deze uitgave mag worden verveelvoudigd, opgeslagen in een geautomatiseerd gegevensbestand, of openbaar gemaakt, in enige vorm of op enige wijze, hetzij elektronisch, mechanisch, door fotokopieën, opnamen of enige andere manier zonder voorafgaande schriftelijke toestemming van Stichting Wageningen Research.

Stichting Wageningen Research is niet aansprakelijk voor eventuele schadelijke gevolgen die kunnen ontstaan bij gebruik van gegevens uit deze uitgave.

Rapport WPR-902 


\section{Inhoud}

Samenvatting

Verkenning klimaatverandering in de open teelten - Startpunt voor adaptatie 7

$1.1 \quad$ Klimaattrends

1.1.1 Het wordt warmer 7

1.1.2 Het wordt natter 9

1.1.3 Het wordt droger 11

1.1.4 De zeespiegel stijgt $\quad 11$

1.2 Regionale klimaatveranderingen 12

$\begin{array}{lll}1.3 & \text { De open teelten en klimaatverandering } & 16\end{array}$

2.1 Aardappel 25

2.1.1 Effecten klimaatverandering op kwaliteit en fysieke opbrengsten $\quad 25$

2.1.2 Effecten klimaatverandering op ziekten en plagen 26

$\begin{array}{lll}2.2 & \text { Zaaiui } & 27\end{array}$

2.2.1 Effecten klimaatverandering op kwaliteit en fysieke opbrengsten $\quad 27$

2.2.2 Effecten klimaatverandering op ziekten en plagen $\quad 28$

$\begin{array}{lll}2.3 & \text { Peen } & 28\end{array}$

2.3.1 Effecten klimaatverandering op kwaliteit en fysieke opbrengsten $\quad 28$

2.3.2 Effecten klimaatverandering op ziekten en plagen 28

2.4 Wintertarwe $\quad 29$

2.4.1 Effecten klimaatverandering op kwaliteit en fysieke opbrengsten 29

2.4.2 Effecten klimaatverandering op ziekten en plagen 30

$\begin{array}{lll}2.5 & \text { Suikerbiet } & 30\end{array}$

2.5.1 Effecten klimaatverandering op kwaliteit en fysieke opbrengsten $\quad 30$

2.5.2 Effecten klimaatverandering op ziekten en plagen 31

3

Adaptatiemaatregelen $\quad 33$

$3.1 \quad$ Longlist 33

3.2 Maatregelen in teeltjaar 2020

3.3 Maatregelen in teeltjaar $2021 \quad 35$

$\begin{array}{lll}3.4 & \text { Factsheet voor adaptatiemaatregelen } & 35\end{array}$

4

$\begin{array}{ll}\text { Conclusie } & 43\end{array}$

$\begin{array}{ll}\text { Literatuur } & 45\end{array}$ 



\section{Samenvatting}

In de publiek private samenwerking (PPS) Klimaatadaptatie in de open teelten wordt doormiddel van onderzoek en expirimenten getracht om de gevolgen van klimaatverandering op de akkerbouw beheersbaar te houden. Dit rapport zet de te verwachten klimaatveranderingen op een rij en toont hoe deze veranderingen de akkerbouw in Nederland zal gaan beïnvloeden. Dat wordt gedaan aan de hand van de vier klimaattrends die globaal de klimaatveranderingen schetsen; Het wordt warmer, het wordt droger, het wordt natter, de zeespiegel stijgt/verzilting. Er wordt in detail ingezoomd op de kwetsbaarheden van de volgende grote akkerbouwgewassen; aardappel, wintertarwe, suikerbiet, zaaiui en peen.

De kwetsbaarheden per gewas zijn in kaart gebracht door een systematisch literatuuronderzoek en inzichten vanuit expertkennis. Hieruit komt naar voren dat het groeiseizoen voor de geselecteerde gewassen door een verwachte hogere gemiddelde temperatuur wordt verlengd. Een toename van natte omstandigheden door klimaatverandering in het voor- en najaar zullen dit positieve effect verminderen door effecten zoals kluitvorming en bodemverdichting. Door een toename van de temperatuur kunnen er meer problemen ontstaan met ziekten en plagen, zo zijn de omstandigheden voor insecten om te overwinteren gunstiger. Met name onder de W-klimaatscenario's nemen de kansen op droogte toe. Voor aardappel kan droogte, in combinatie met hitte, voor meer problemen zorgen met doorwas. Bij de zaaiui zullen de opbrengsten mogelijk stagneren doordat hogere temperaturen en droogte de groeiperiode verkorten. Daarnaast kunnen een toenemend aantal droge periodes meer problemen geven met schimmels zoals Fusarium en Valse meeldauw. Peen kan door de hogere temperaturen meer problemen krijgen met wortelvlieg en de wortelmineervlieg. Voor wintertarwe neemt het risico van schade door strenge vorst af. Ook wordt er eerder aan de temperatuursom voldaan waardoor er eerder geoogst kan worden. Voor suikerbiet neemt het risico van aantasting aan de jonge plantjes door vorst in het voorjaar af, echter neemt het risico's van ziekten plagen naar verwachting toe. Wat betreft verzilting zijn met name aardappel, ui en peen kwetsbaar, terwijl dat voor suikerbiet en wintertarwe minder het geval is.

Op basis van de eerst resultaten van de experimenten met klimaatadaptatiemaatregelen die in deze PPS onderzocht worden, aangevuld met literatuur, zijn factsheets ontwikkeld. Deze factsheets tonen eenduidig de effectiviteit op het inspelen op de klimaattrends en de toepasbaarheid in termen van kennis, kosten en grondsoort van deze adaptatiemaatregelen. De factsheets zijn los beschikbaar, maar zijn ook in dit rapport toegevoegd. De volgende maatregelen zijn geëvalueerd: Duurzaam opheffen van ondergrondverdichting, groenbemesters, Optimale vochtvoorziening in zetmeelaardappelen, Erosiestoppers, Breedspoor, en Transformer. De meeste van deze maatregelen zijn effectief op de klimaattrends het wordt droger en het wordt natter, omdat ze het water- en bodembeheer verbeteren op het boerenbedrijf. Voor het opstellen van de factsheets is gebruikt gemaakt van de kennis en ervaringen van de andere werkpakketten in de PPS.

De auteurs zijn Derk van Balen (WUR), Carina Rietema (SPNA) en Harm de Boer (Delphy) dankbaar voor hun inhoudelijke bijdrages aan de dit rapport en de invulling van de factsheets vanuit hun eigen werkpakketten in de PPS Klimaatadaptatie Open Teelten. We willen ook Marjan Toren (WUR) bedanken voor het meedenken en ontwikkelen van de factsheets. 


\section{Verkenning klimaatverandering in de open teelten - Startpunt voor adaptatie}

In dit hoofdstuk wordt de verwachte klimaatverandering toegelicht en geprojecteerd op de landbouwregio's van Nederland.

\section{$1.1 \quad$ Klimaattrends}

In dit rapport wordt aangesloten bij de klimaattrends die het meeste impact hebben en beschreven zijn door het Kennisportaal Ruimtelijke Adaptatie. Hierbij volgen wij de vier klimaattrends zoals door hen beschreven in de Nationale Adaptatie Strategie (NAS). Dat zijn; het klimaat wordt: 1. warmer, 2. natter, 3. droger en 4. de zeespiegel stijgt. Bij deze trends is specifiek gekeken wat de impact voor de landbouw is. Voor elk van de vier bovenstaande klimaattrends wordt weergegeven wat de veranderingen zijn en wat de gevolgen van deze veranderingen voor de landbouw zijn. Zie daarvoor ook de NAS adaptatietool: https://nas-adaptatietool.nl/ (NAS, 2019).

In eerder onderzoek (Daan Verstand et al., 2020) is op basis van deze klimaattrends uitgebreid beschreven wat de impact hiervan is. Hieronder een beknopte weergave van deze klimaattrends en voorspelde veranderingen per klimaatscenario met de gevolgen voor de landbouw omdat dit dient als verder uitgangspunt voor dit onderzoek.

\subsubsection{Het wordt warmer}

Figuur 1 laat het verloop van de gemiddelde temperatuur in Nederland vanaf 1901 zien. Duidelijk is dat er de laatste 30 jaar sprake is van een significante stijging die volgens de vier klimaatscenario's van het KNMI ook naar de toekomst toe doorzet (Klein Tank, Beersma, Bessembinder, Van den Hurk, \& Lenderink, 2014).

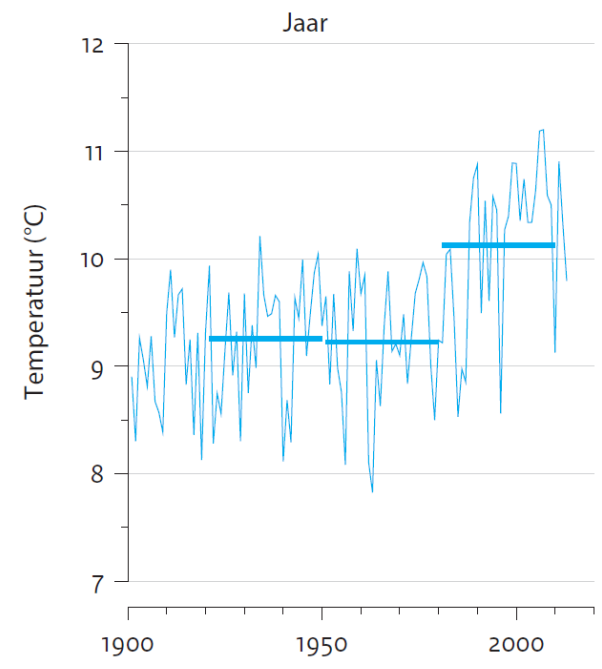

Figuur 1; waargenomen jaargemiddelde temperatuur in de Bilt, horizontale lijnen zijn gemiddelden over 30 jaar (Klein Tank et al., 2014).

Deze trend heeft, zoals ook te zien is in de NAS adaptatietool, naast de negatieve effecten ook een aantal positieve effecten voor de landbouw, zoals snellere gewasgroei of een vroegere oogst. Een warme winter wordt over het algemeen wel als negatief gezien omdat hiermee de overlevingskansen 
van ziekten en plagen toeneemt. Dit zorgt voor een toename van ziekteverwekkers en daardoor ook voor een toename van ziekten en plagen in gewassen.

Figuur 2 toont per klimaatscenario van het KNMI (Klein Tank et al., 2014) de toename van de temperatuur over de maanden van het jaar voor 2050, ten opzichte van de referentie periode 19812010. Zowel de gemiddelde maximum temperatuur, als de gemiddelde minimum temperatuur stijgen in elk scenario. De gemiddelde maximum temperatuur over een jaar in de referentie periode is 14.2 graden, de gemiddelde minimum temperatuur in de referentieperiode over het jaar is 6.0 graden.

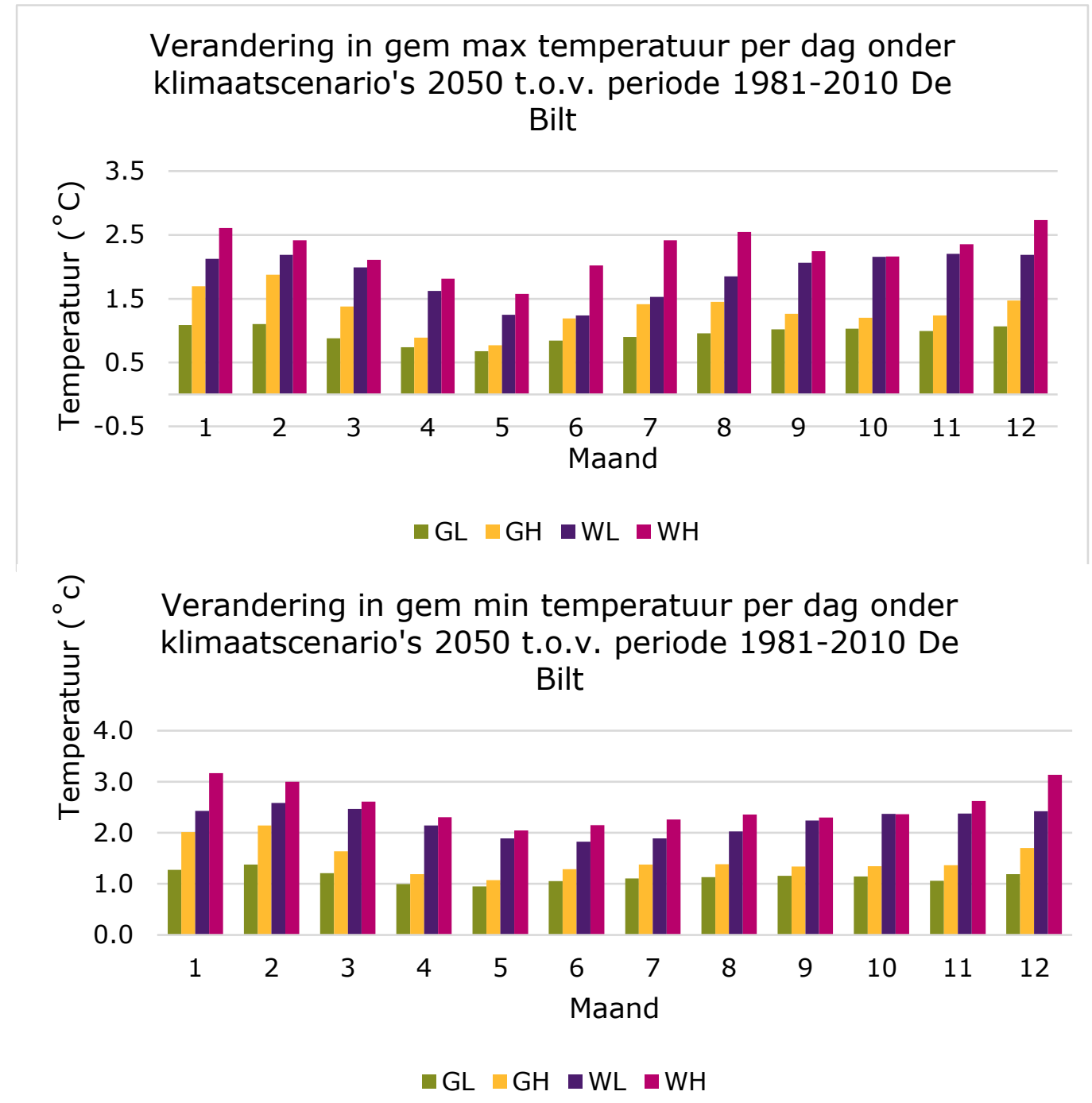

Figuur 2. Per klimaatscenario wordt de verwachte temperatuurverandering per maand getoond voor 2050, ten opzichte van de periode 1981-2010. In het bovenste paneel de verandering van de gemiddelde maximum temperatuur, en in het onderste de gemiddelde minimum temperatuur. Data: KNMI 2014, figuur: eigen bewerking. 


\subsubsection{Het wordt natter}

Deze trend manifesteert zich vooral in de toename van extremen. Niet het aantal neerslagdagen neemt toe, maar vooral in de hoeveelheid neerslag wat in korte tijd valt. Daarnaast komen langdurige natte periodes afgewisseld met langdurige droge periodes vaker voor. Dit heeft niet alleen gevolgen voor de mogelijkheden van bewerking of oogst die hierdoor beperkt worden, maar ook voor de kwaliteit van producten. Kwetsbare gewassen kunnen verloren gaan als na een hevige bui het water niet snel genoeg afgevoerd kan worden. Onderstaande Figuur 3 geeft aan dat de jaarlijkse hoeveelheid neerslag tussen 1910 en 2013 met $26 \%$ is toegenomen.

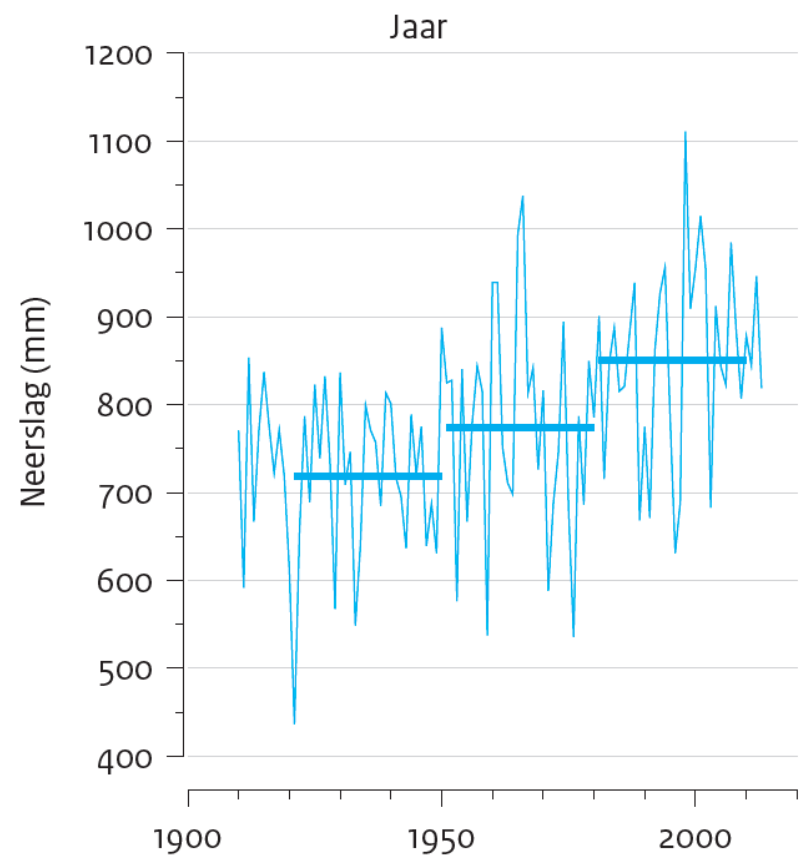

Figuur 3; waargenomen jaarlijkse neerslag in Nederland (A. Klein Tank et al., 2014). Door de toename van de temperatuur is volgens het KNMI ook de hoeveelheid waterdamp in de lucht toegenomen sinds 1950. Dit verklaart gedeeltelijk de toename van de jaarlijkse hoeveelheid neerslag. Het effect op zware buien is nog groter. Uit waarnemingen blijkt dat bij de meest extreme buien de hoeveelheid neerslag per uur toeneemt met ongeveer $12 \%$ per graad opwarming, zo geeft het KNMI aan. Vanwege de verwachtte verdere temperatuurstijging, verwacht het KNMI in al haar klimaatscenario's een verdere stijging van jaarlijkse neerslaghoeveelheid (Klein Tank et al., 2014). Alle seizoenen met uitzondering van de zomer zullen natter worden. Daarnaast geeft een temperatuurstijging een grotere omvang van neerslagextremen, zoals afgebeeld in Figuur 4, waarbij rechts gerekend is met een temperatuurstijging van 2 graden Celsius.
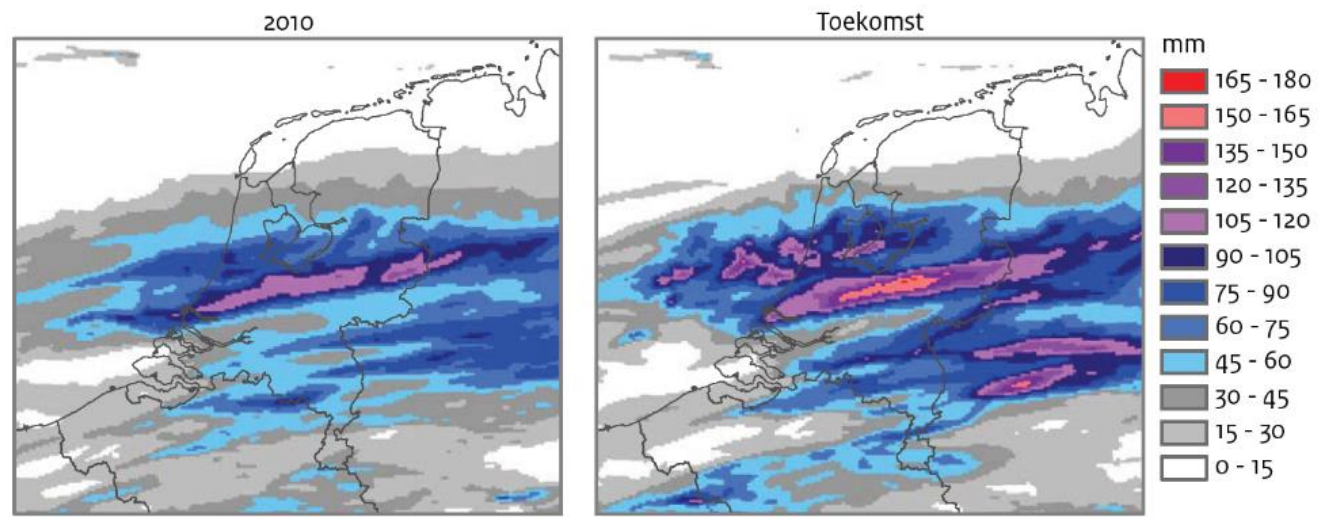

Figuur 4; Situatie van een bui met meer dan $100 \mathrm{~mm}$ neerslag in twee dagen in augustus 2010 (links), en de transformatie van deze bui naar een 2 graden warmer klimaat in de toekomst (rechts). (Klein Tank et al., 2014). 
Figuur 5 toont per klimaatscenario de verwachtte neerslag per maand. Te zien is dat inderdaad in alle vier de klimaatscenario's en lente, herfst en winter natter worden. De orde van grote verandering is maximaal bijna $20 \%$ toename van de neerslag (onder WH in de wintermaanden) ten opzichte van de periode 1981-2010. In de zomer wordt het met name onder het GH en WH scenario droger. De gemiddelde jaarneerslag over de periode $1981-2010$ in de Bilt was $887 \mathrm{~mm}$ per jaar.



Figuur 5. Verandering van de neerslaggemiddelden in $\mathbf{~} \mathrm{m}$ (bovenste paneel) en procentueel (onderste paneel), per klimaatscenario per maand, ten opzichte van de neerslag in de periode 1981-2010 Data: KNMI 2014, figuur: eigen bewerking. 


\subsubsection{Het wordt droger}

Deze trend lijkt tegenstrijdig met voorgaande trend. KNMI verwacht een toename van neerslag in alle seizoenen, met uitzondering van de zomer (zie ook Figuur 5). De verklaring hiervoor is de hogere temperatuur waardoor de hoeveelheid waterdamp in de lucht toeneemt. Net zoals langdurige natte periodes toenemen, is dit ook het geval met langdurige droge periodes. In 2018 en 2019 is dit effect, met name in gebieden waar geen beregeningsmogelijkheden zijn, voor de landbouw zeer duidelijk zichtbaar geweest. Regionaal ontstaan hierdoor grote opbrengstverschillen, afhankelijk van de beschikbaarheid van zoet water.

De W-scenario's laten een stijging zien van het aantal droge periodes. De G-scenario's blijft de neerslag in de zomer gelijk of neemt zelfs iets toe. In het $W_{L}$ - en $W_{H}$-scenario neemt rond 2050 (20362065) voor weerstation Eelde de verwachte frequentie (aantal keren van optreden per 30 jaarsperiode) van een periode van 30 dagen met een neerslag minder dan $10 \mathrm{~mm}$ in juli en augustus toe

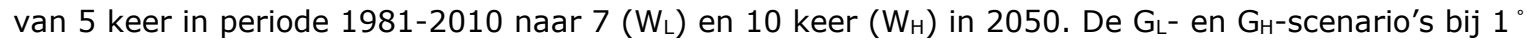
$C$ stijging laten een lichte daling zien van respectievelijk 4 en 3 keer. Alle toekomstige klimaatscenario's laten een stijging zien van hittegolven ten opzichte van de referentieperiode, waar deze 11 keer voorkwam. Naar verwachting neemt het aantal hittegolven onder het GL- en $W_{H}$-scenario toe naar respectievelijk 20 en 36 keer. Dat kan door een toename van de evapo-transpiratie ook zorgen voor droogte en schade aan de gewassen.

\subsubsection{De zeespiegel stijgt}

Deze trend is voor de landbouw vooral van invloed op de mate van verzilting van het water. Zeker in combinatie met droge en warme zomers wordt de beschikbare zoetwatervoorraad kleiner. De beschikbare zoetwatervoorraad bevindt zich bovenop het relatief ondiepe zoute grondwater in een zoetwaterlens. Deze worden jaarlijks aangevuld door het jaarlijkse neerslagoverschot. Dit neerslagoverschot wordt kleiner als gevolg van de droge en warme omstandigheden. Direct aan de kust vindt er daarnaast ook indringing plaats van zout zeewater op de plekken waar dit water hoger staat dan het land. Een stijging van de zeespiegel verergert dit probleem zodat het tot gevolg kan hebben dat het oppervlaktewater kan verzilten of beregeningsmogelijkheden verder beperkt worden. Als wordt uitgegaan van de vier KNMI-klimaatscenario's, dan kan tot 2050 maximaal een kwart (onder W+-scenario) van het huidige landbouwareaal te maken krijgen met lichte tot ernstige verzilting (Prins, 2011). Overigens is dit in de praktijk behoorlijk gecompliceerd. Er is allereerst geen éénduidig meetmethode voor de aanduiding van "lichte" of "ernstige" verzilting. Voor drinkwater wordt een grens aangehouden voor maximaal $150 \mathrm{mg} \mathrm{Cl} / \mathrm{l}$. Voor landbouwkundig gebruik (volle grond) wordt water met waardes tot 200 of $250 \mathrm{mg} \mathrm{Cl} / \mathrm{l}$ nog tot zoet water gerekend. Bij hogere waardes is in een glijdende schaal sprake van steeds ergere verzilting. Daarnaast zijn de gevolgen van verzilting (gewasschade) niet alleen sterk afhankelijk van het soort gewas, maar ook van veel andere factoren zoals gewasstadium, duur van de blootstelling, bodemtype, temperatuur, vochtgehalte en $\mathrm{pH}$ (van Bakel, Blom-Zandstra, \& Stuyt, 2018).

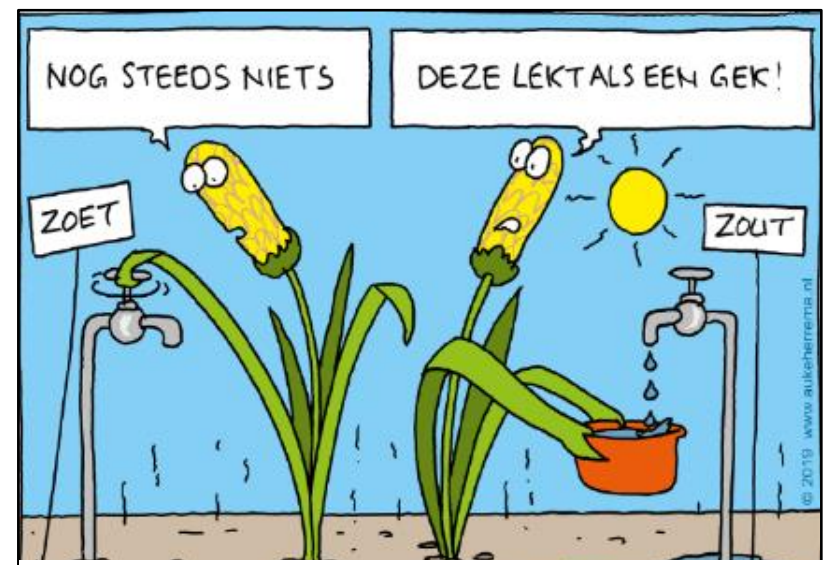

Figuur 6. Illustratie van verzilting. (Ministerie van LNV, 2020) 


\subsection{Regionale klimaatveranderingen}

De klimaattrends zoals door het KNMI vastgelegd in de KNMI '14 klimaatscenario's laten zien dat de vier scenario's, die vanuit internationaal perspectief voor de Nederlandse situatie zijn doorgerekend, voor heel Nederland gelden. Toch is het van belang, zeker voor de landbouw, om de regionale context hierbij mee te nemen. De verschillende klimaatscenario's werken in Nederland niet even sterk door. Zo geeft het KNMI als toelichting bij de klimaatscenario's van 2014 op haar website aan: "regionale temperatuurverschillen tussen kust en binnenland in de zomer nemen hierdoor toe. Op koude winterdagen is de opwarming in het oosten groter dan in de kustgebieden, waardoor de bestaande regionale verschillen juist afnemen".

De klimaattrend "Het wordt warmer"

De kaartjes van Figuur 7 geven de regionale verschillen voor Nederland van de klimaattrend " het wordt warmer" aan door het aantal hittedagen nu en in 2050 (WH-scenario KNMI '14) te tonen. Voor de trend "het wordt warmer" zijn deze regionale veranderingen in temperatuur niet overal even sterk. Hoe verder landinwaarts, hoe meer het aantal hittedagen per jaar toeneemt. In de kuststreek is het effect van de Noordzee sterker aanwezig, waardoor het aantal hittedagen per jaar hier veel minder toeneemt.
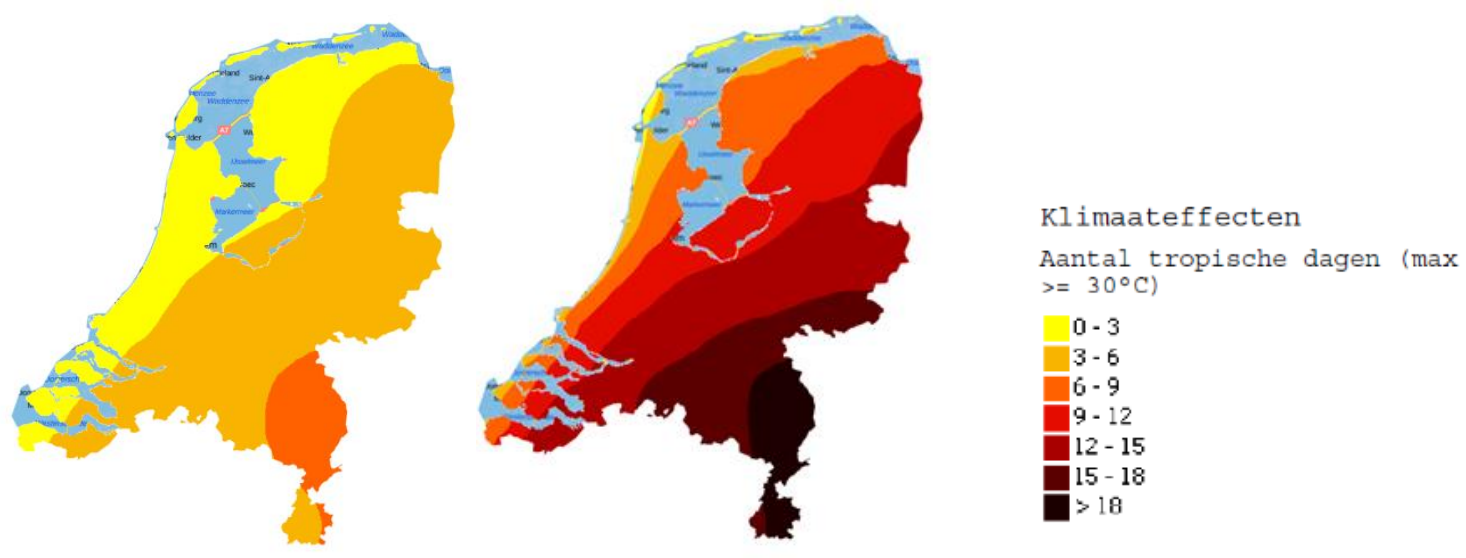

Figuur 7; Huidige situatie (links) en situatie in 2050 (rechts) met aantal tropische dagen per jaar volgens het WH-scenario van het KNMI. (Klimaateffectatlas, 2020)

De klimaattrend "Het wordt natter"

De klimaattrend "het wordt natter" wordt goed weergegeven door Figuur 8 waar links de huidige jaarlijkse neerslaghoeveelheid wordt weergegeven. Regionale verschillen zijn hierbij goed zichtbaar. Rechts staat de kaart met de verwachte jaarlijkse neerslaghoeveelheid in 2050 volgens het WHscenario van het KNMI.
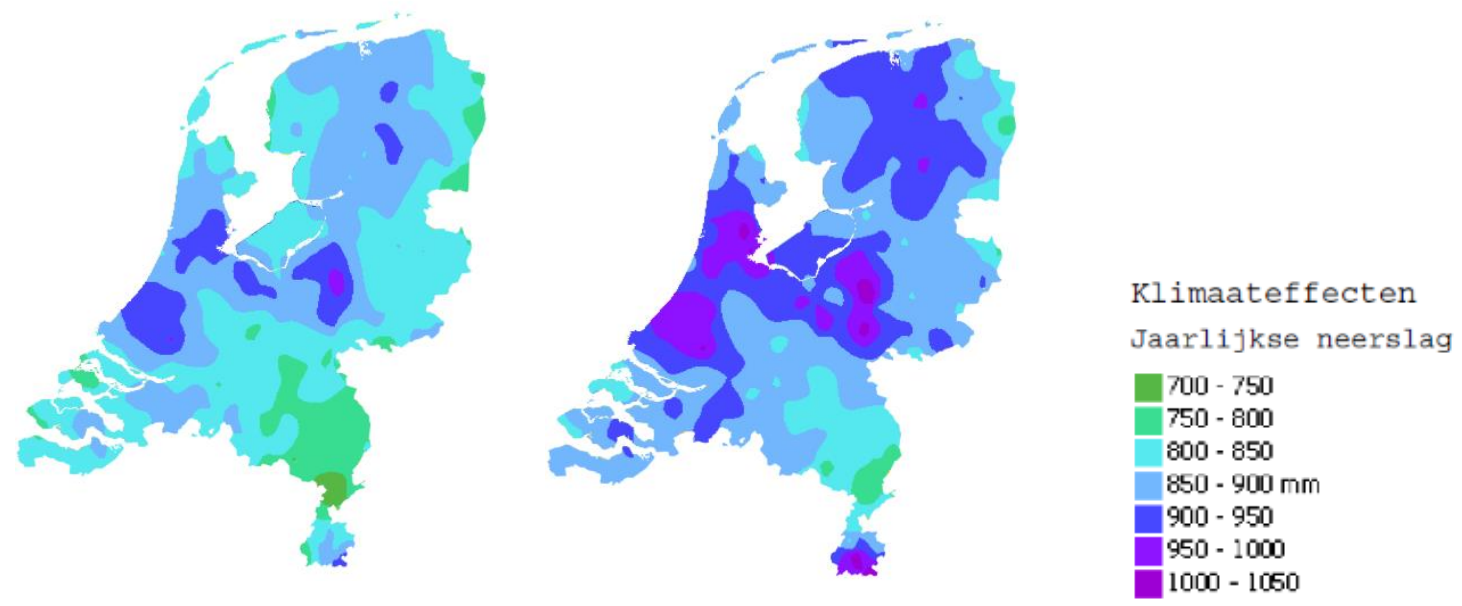

Figuur 8; Huidige jaarlijkse neerslag (links) en situatie in 2050 (rechts) volgens het WH-scenario, Bron KNMI (Klimaateffectenatlas, 2020) 
Hieruit blijkt dat de jaarlijkse hoeveelheid op de meeste plaatsen in Nederland toeneemt met ca. 50 mm per jaar ten opzichte van nu, al lijkt de toename in de kustregio en het midden van het land wat groter te zijn dan in het oosten van het land. Daarbij is het goed om te beseffen dat in de achterliggende eeuw de jaarlijkse neerslaghoeveelheid al met ca. $100 \mathrm{~mm}$ per jaar is toegenomen. De regionale verschillen die er nu aanwezig zijn, blijven ook in dit scenario voor 2050 gehandhaafd en worden in sommige gevallen extremer. Zijn er nu nog maar enkele gebieden in Nederland waar de totale jaarlijkse neerslagsom gemiddeld hoger is dan $900 \mathrm{~mm}$ per jaar, wordt dit naar 2050 een aanzienlijk deel van Nederland.

Naast de toename van de totale jaarlijkse neerslagsom is een $2^{\mathrm{e}}$ effect van de klimaattrend "het wordt natter" dat de kans op neerslagextremen toeneemt. Onderstaande kaart (Figuur 9) geeft aan in welke regio's deze neerslagextremen op dit moment bovengemiddeld, gemiddeld of minder dan gemiddeld voorkomen. Het risico op neerslagextremen is met name in de kustprovincies en Zuid Limburg hoger, terwijl dit risico in Noord-Nederland en een groot deel van Oost-Nederland lager dan gemiddeld is.

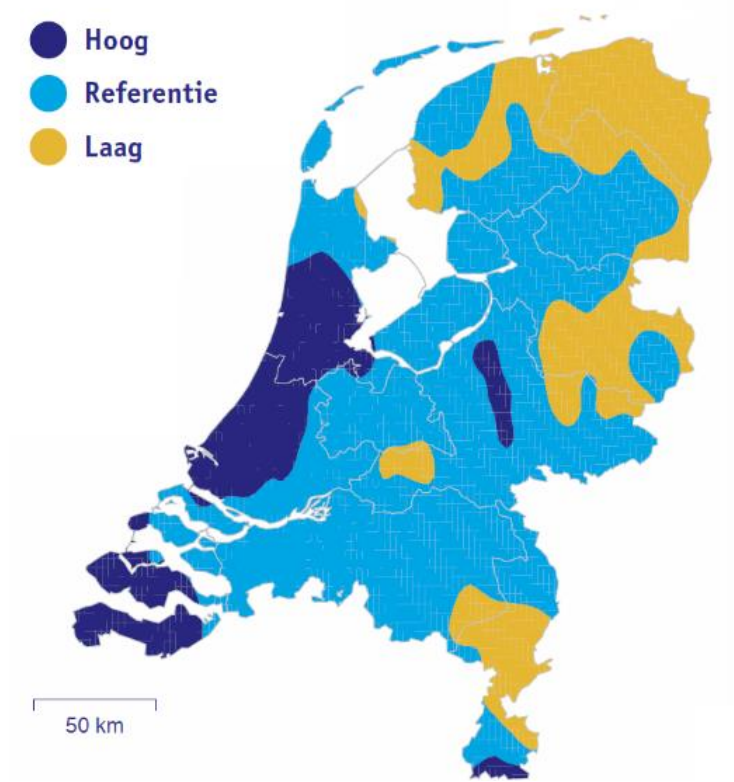

Figuur 9; Huidige relatieve kans op extreme neerslag per regio, (STOWA, 2019).

Figuur 9 geeft per regio goed weer wat de huidige relatieve kans is op extreme neerslag. Met name in de donkerblauw gekleurde gebieden is de kans op extreme neerslag het grootst.

Tabel 1 laat zien dat de kans op extreme neerslag in alle klimaatscenario's toeneemt, maar ook dat de verschillen regionaal verder uiteen gaan lopen. In de gebieden waar nu de meeste kans op extreme neerslag is (donkerblauwe gebieden in Figuur 9, in de tabel de kolom "upper"), neemt de kans op extreme neerslag in de toekomst dubbel zo hard toe als in de gebieden met de minste kans op extreme neerslag (bruine gebieden, bij de tabel de kolom "lower"). Zo neemt voor het WH scenario rond 2050 in de donkerblauwe (upper) gebieden, zal de relatieve kans op extreme neerslag met $21.3 \%$ toenemen, terwijl dat in het zelfde scenario in de bruine (lower) gebieden 'slechts' met $11.1 \%$ toeneemt (STOWA, 2019). 
Tabel 1; Procentuele verandering van de kans op extreme neerslag voor de 3 gebieden uit Figuur 9 en verschillende klimaatscenario's, (STOWA, 2019)

VERANDERING VAN DE EXTREME NEERSLAG VOOR UURSOMMEN EN TWEE-UURSSOMMEN IN DE KLIMAATSCENARIO'S

\begin{tabular}{lccc}
\hline Scenario & \multicolumn{3}{c}{ Verandering tov 2014 [\%] } \\
\hline 2030 & Lower & Center & Upper \\
\hline 2050_GL & 3,9 & 5,8 & 7,7 \\
2050_GH & 3,9 & 5,8 & 7,7 \\
2050_WL & 4,9 & 7,4 & 9,8 \\
2050_WH & 10,2 & 14,9 & 19,6 \\
2085_GL & 11,1 & 16,2 & 21,3 \\
2085_GH & 6,4 & 9,6 & 12,8 \\
2085_WL & 7,2 & 11,2 & 15,2 \\
2085_WH & 20,1 & 30,6 & 41,1 \\
\hline
\end{tabular}

\section{De klimaattrend "Het wordt droger"}

De klimaattrend "het wordt droger", doet zich vooral voor in de zomerperiode. Overal in Nederland neemt in deze periode de kans op langere droge periodes toe. De impact van deze verandering is echter niet over heel Nederland gelijk. Er zijn 2 factoren die ervoor zorgen dat het binnenland van Nederland meer last krijgt van de droogte.

In het binnenland is de toename van zonnestraling groter dan in de kustregio zoals in Figuur 10 links te zien is, terwijl de zomerneerslag met in het binnenland achterblijft ten opzichte van de kustregio. Neem daarbij de extra toename van de potentiële verdamping in het binnenland zoals uit Figuur 10 rechts blijkt en het is duidelijk dat de trend daarom is dat de kans op droogteperiodes in het binnenland groter wordt ten opzichte van de kustregio. Een bijkomende factor is dat wateraanvoer in het binnenland voornamelijk vanuit regen plaatsvindt, terwijl meer aan de kust ook water aangevoerd kan worden via de grote rivieren. Hierdoor is het binnenland extra gevoelig voor veranderingen in neerslag in de zomermaanden (KNMI, 2020).

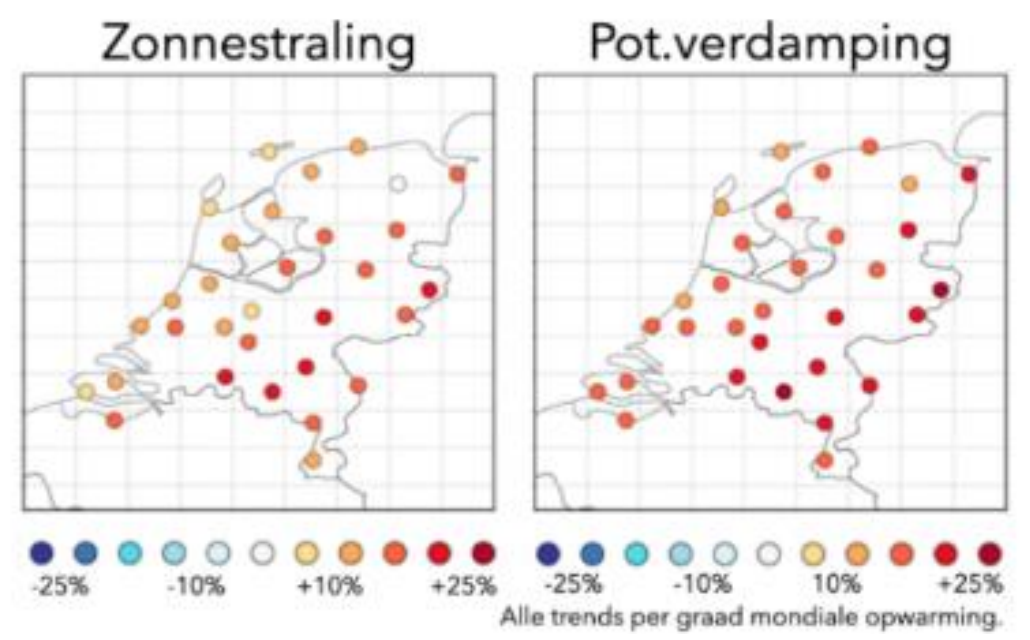

Figuur 10; Langjarige trend met regionale verandering zonnestraling en potentiële verdamping per graad opwarming (KNMI, 2020).

Voor de landbouw zal de noodzaak van beregening hierdoor toenemen. Gebieden met een verhoogd droogterisico en onvoldoende beregeningsmogelijkheden zijn extra kwetsbaar. Delen van OostNederland en Zuidelijke zand- en lossgronden springen er hierbij uit omdat dit de gebieden zijn die extra kwetsbaar zijn voor droogte en in een deel van deze gebieden onvoldoende beregeningsmogelijkheden zijn. Voor het Zuidwestelijk kleigebied geldt geldt eveneens een kwetsbaarheid vanwege de beperkte beregeningsmogelijkheden in een deel van dit gebied. De mogelijkheden om te beregenen zullen afnemen. Door de inklinkende bodem en een stijgende zeespiegel zal er een grotere optwaartse druk van brak grondwater ontstaan waardoor de 
zoetwaterlenzen, welke nu belangrijke bronnen voor beregingingen zijn, zullen verdwijnen. Hierdoor neemt de mogelijkheid af om uit deze zoetwaterlenzen te beregenen. Tegelijkertijd zijn er inderdaad slimme intiatieven om water vast te houden waardoor er water kan worden bespaard of vastgehouden.

\section{De klimaattrend "De zeespiegel stijgt"}

Zoals hiervoor aangeven, is bij deze klimaattrend voor de landbouw vooral het risico van verzilting van belang. Het is duidelijk dat dit risico met name in de kustregio fors toeneemt zoals Figuur 11 ook laat zien. Hierbij is met name het Noordelijk Kleigebied kwetsbaar, omdat hier direct aan de kust al veel grond voor akkerbouwmatige doeleinden in gebruik is (Spaarwater, 2019).

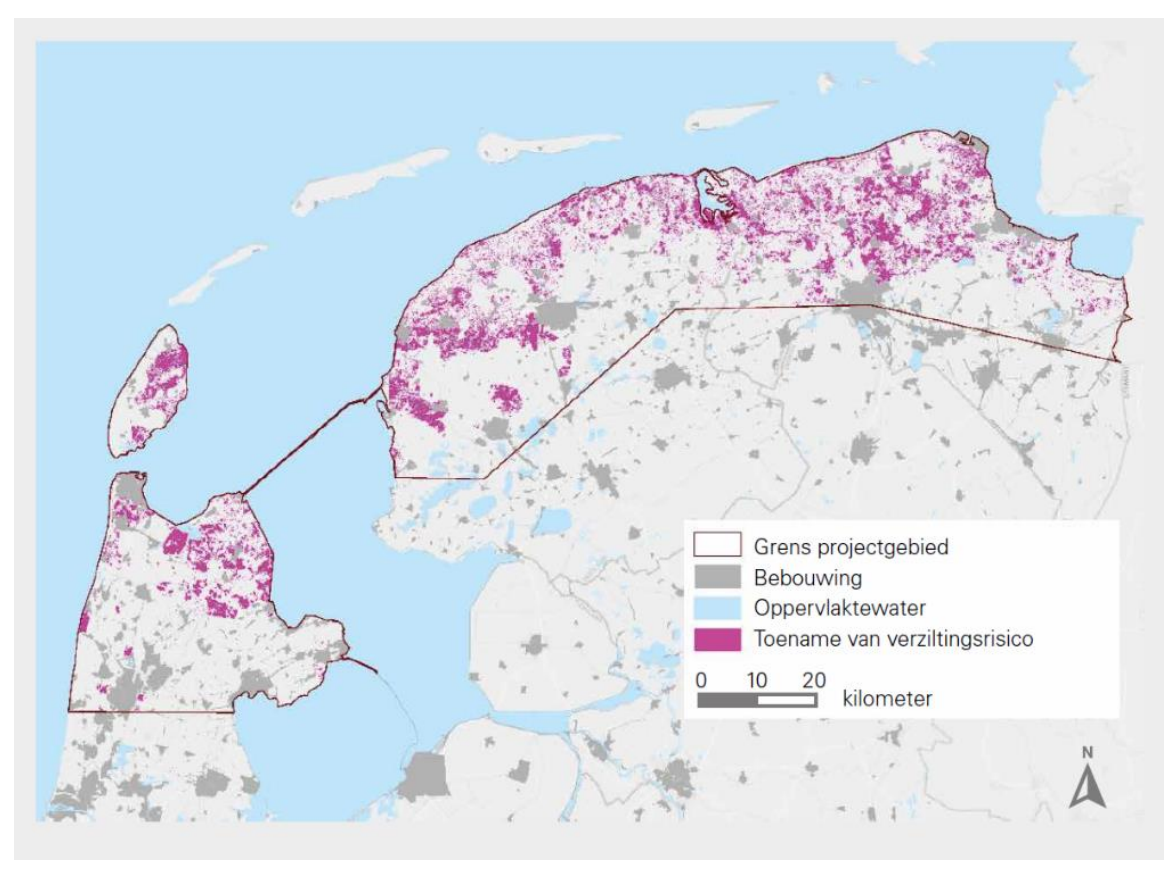

Figuur 11; Toename van het verziltingsrisico in het projectgebied in 2050. De kaart is geschikt voor gebruik op regionaal niveau; het risico kan in werkelijkheid lokaal afwijken (Spaarwater, 2019).

Een soortgelijke situatie doet zich voor langs de kust van Zuidwest Nederland. Door de stijging van de zeespiegel, neemt de invloed van het zoute zeewater op het grondwater toe. Dit grondwater wordt zouter en het niveau hiervan stijgt eveneens. Het lichtere zoete water heeft daardoor minder plaats. Wanneer verzilting te ver doorgaat, kan het zout tot aan de wortel van de plant komen, wat groeischade tot gevolg heeft. Daarnaast worden de mogelijkheden van beregening beperkter. 


\subsection{De open teelten en klimaatverandering}

Het is duidelijk dat deze regionale verschillen ook gevolgen voor de landbouw kunnen hebben. Van belang is daarom om een goed beeld te krijgen van de regionale verschillen in de diverse akkerbouwgebieden, zodat ingezet kan worden op de juiste maatregelen. Hiervoor worden de 4 klimaattrends als leidraad gebruikt en wordt een uitsplitsing gemaakt in de volgende 8 belangrijkste akkerbouwgebieden (Smit en Jager 2018).

1. Noordelijk kleigebied: Bouwhoek en Hogeland

2. IJsselmeerpolders en Noord-Holland (gedeeltelijk)

3. Zuidwestelijk kleigebied

4. Veenkoloniën

5. Noordelijke zand- en dalgronden

6. Oostelijke zandgebieden

7. Rivierkleigebied

8. Zuidelijke zandgebieden en löss.

In Figuur 12 worden deze gebieden grafisch weergegeven.

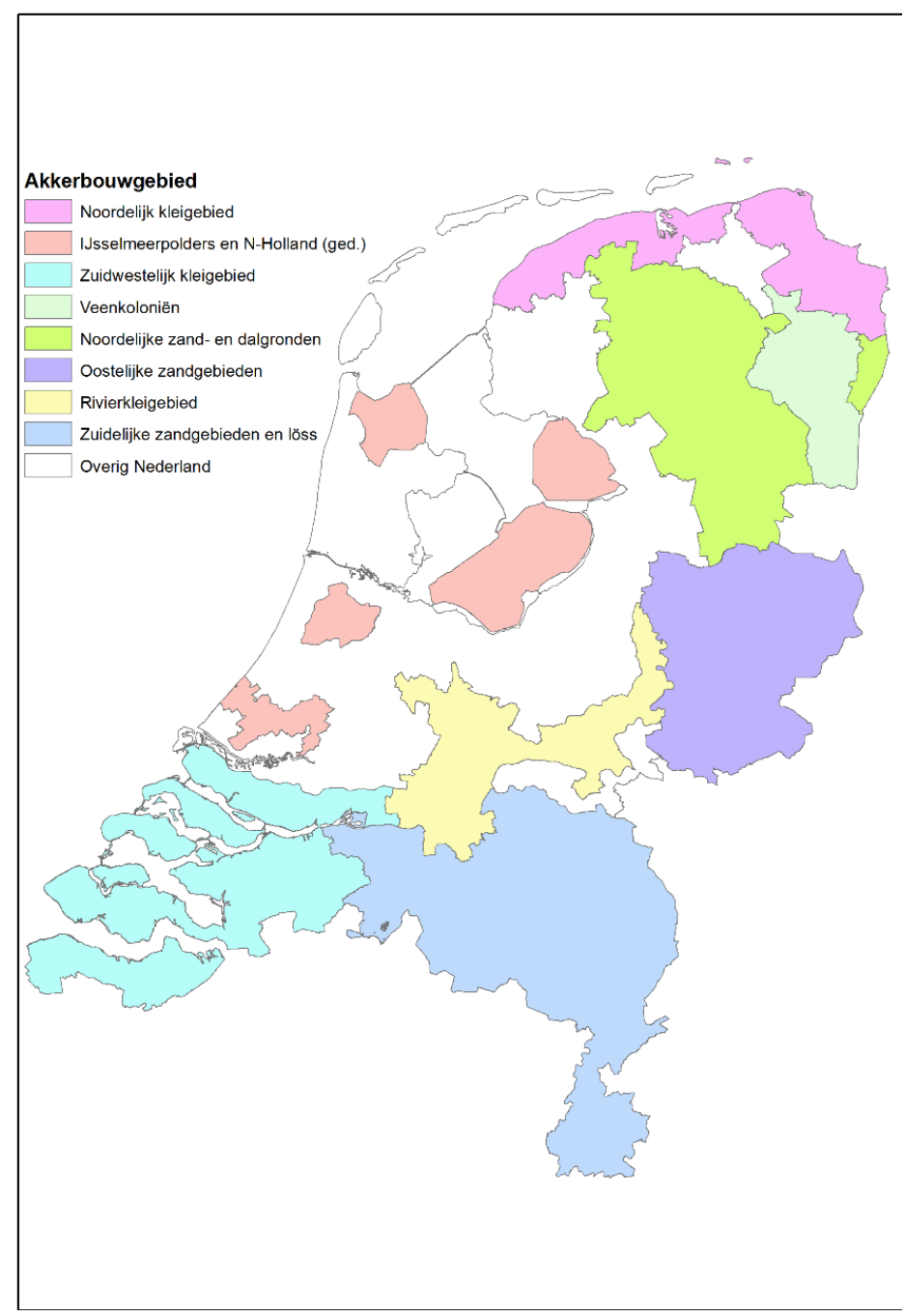

Figuur 12; Overzicht akkerbouwgebieden in Nederland, Bron: Smit en Jager 2018.

In 2017 had Nederland een totaal areaal cultuurgrond van ruim 1,8 miljoen ha. Het areaal akkerbouw is na aftrek van blijvend grasland, overige cultuurgrond en exclusief 205.000 ha mais en 247.000 ha tijdelijk grasland ca 509.000 ha. Van dit areaal lag 94\% in de acht onderscheiden akkerbouwgebieden; de resterende $6 \%$ lag verspreid in overige, kleinere gebieden. De belangrijkste akkerbouwgebieden qua aandeel van het totale akkerbouwareaal waren het Zuidwestelijk kleigebied (28\%), IJsselmeerpolders en Noord-Holland (17\%), het Noordelijke kleigebied (14\%) de Zuidelijke 
zandgebieden en löss (13\%) en de Veenkoloniën (10\%). Het rivierkleigebied omvatte het kleinste areaal akkerbouwgewassen (2\%).

Tabel 2 geeft aan wat de belangrijkste teelten qua oppervlakte zijn per teeltgebied. Het aandeel hiervan verschilt per teeltgebied. Bij aardappelen kan nog een verdere diversificatie gemaakt worden in poot-, consumptie- en zetmeelaardappelen. Bij granen kan deze diversificatie eveneens worden gemaakt voor de verschillende soorten granen zoals tarwe en gerst.

Tabel 2; Arealen cultuurgrond en akkerbouw totaal en van de belangrijkste gewassen per teeltgebied in 2017. Bron: Landbouwtelling CBS 2019.

\begin{tabular}{|c|c|c|c|c|c|c|c|}
\hline Akkerbouwgebied & $\begin{array}{l}\text { Cultuurgrond } \\
\text { totaal }\end{array}$ & $\begin{array}{l}\text { Akkerbouw } \\
\text { totaal }\end{array}$ & Granen & $\begin{array}{l}\text { Aard- } \\
\text { appelen }\end{array}$ & Suikerbieten & $\begin{array}{l}\text { Groenten } \\
\text { (akkerbouw- } \\
\text { matig) }\end{array}$ & $\begin{array}{l}\text { Waar- } \\
\text { van uien }\end{array}$ \\
\hline Noordelijk kleigebied & 142.869 & 71.706 & 33.451 & 20.672 & 10.690 & 3.290 & 2.473 \\
\hline Zuidwestelijk kleigebied & 226.905 & 141.462 & 46.978 & 35.991 & 20.858 & 22.349 & 14.987 \\
\hline $\begin{array}{l}\text { Oostelijke } \\
\text { zandgebieden }\end{array}$ & 199.274 & 14.247 & 5.830 & 5.853 & 1.527 & 297 & 130 \\
\hline Rivierkleigebied & 95.922 & 10.356 & 4.834 & 1.611 & 1.888 & 711 & 401 \\
\hline $\begin{array}{l}\text { Zuidelijke } \\
\text { zandgebieden en löss }\end{array}$ & 263.250 & 67.396 & 20.233 & 19.242 & 13.109 & 8.878 & 1.937 \\
\hline
\end{tabular}

Wat opvalt is dat van het totale areaal akkerbouw, 4 hoofdteelten eruit springen die verreweg het grootste deel van het bouwplan en van het totaal areaal in Nederland vullen. Uit bovenstaande tabel blijkt het volgende: Deze 4 hoofdteelten tezamen zijn goed voor het gebruik van $87 \%$ van het Nederlandse akkerbouwareaal. Bovenstaande percentages zijn uiteraard wisselend per teeltgebied. Tabel 3 geeft de totalen van de landbouwtelling 2019 weer (CBS, 2019), waarbij wortelen extra zijn opgenomen vanwege de plaats die dit gewas in sommige teeltgebieden inneemt. Tevens zijn enkele subcategorieën aangegeven.

Tabel 3; Areaal gewas ten opzichte van totaal, situatie 2019. Bron: Landbouwtelling CBS 2019

\begin{tabular}{|c|c|c|c|c|c|c|}
\hline Situatie 2019 & Totaal & Granen & Aardappelen & Suikerbieten & Uien & Wortelen \\
\hline \multirow{4}{*}{$\begin{array}{l}\text { aantal ha. } \\
\text { akkerbouw }\end{array}$} & 531.930 & 179.780 & 167.520 & 79.180 & 36.890 & 9.680 \\
\hline & & $\begin{array}{l}\text { w.v. } 33.700 \\
\text { gerst }\end{array}$ & $\begin{array}{l}\text { w.v. } 78.890 \text { cons. } \\
\text { aardappelen }\end{array}$ & & $\begin{array}{l}\text { w.v. } 8.860 \\
\text { plantuien }\end{array}$ & $\begin{array}{l}\text { W.v. } 2.800 \\
\text { waspeen }\end{array}$ \\
\hline & & $\begin{array}{l}\text { w.v. } 121.060 \\
\text { tarwe }\end{array}$ & $\begin{array}{l}\text { w.v. } 43.690 \\
\text { pootaardappelen }\end{array}$ & & $\begin{array}{l}\text { w.v. } 27.580 \\
\text { zaaiuien }\end{array}$ & $\begin{array}{l}\text { w.v. } 6.880 \\
\text { winterpee } \\
n\end{array}$ \\
\hline & & & $\begin{array}{l}\text { w.v. } 44.950 \\
\text { zetmeelaardappele } \\
\mathrm{n}\end{array}$ & & & \\
\hline $\begin{array}{l}\text { Percentage } \\
\text { akkerbouw } \\
\text { areaal }\end{array}$ & $100 \%$ & $34 \%$ & $31 \%$ & $15 \%$ & $7 \%$ & $2 \%$ \\
\hline
\end{tabular}


De diverse teeltgebieden hebben elk hun kenmerkende eigenschappen qua grondsoort, landschap en bouwplan. Samengevat geeft dit het volgende beeld in Tabel 4 (Smit \& Jager, 2018).

Tabel 4; Eigenschappen per akkerbouwgebied. Bron: (Smit \& Jager, 2018).

\begin{tabular}{|c|c|c|c|}
\hline Akkerbouwgebied & $\begin{array}{l}\text { Grondsoort (meest } \\
\text { voorkomend) }\end{array}$ & Landschap & Bouwplan (veel voorkomend) \\
\hline Noordelijk kleigebied & Klei / zavel & $\begin{array}{l}\text { Polderlandschap met } \\
\text { dijken en kwelders, } \\
\text { cultuurhistorische } \\
\text { waarden }\end{array}$ & $\begin{array}{l}\text { Algemeen: } 1: 4 \text { pootaardappel - } \\
\text { wintertarwe - suikerbiet - } \\
\text { wintertarwe; Oldambt: } 3: 4 \text { bijna } \\
\text { continu wintertarwe met enige } \\
\text { koolzaad, suikerbiet en aardappel }\end{array}$ \\
\hline $\begin{array}{l}\text { IJsselmeerpolders } \\
\text { en } \mathrm{N} \text {-Holland } \\
\text { (gedeeltelijk) }\end{array}$ & Klei / zavel & $\begin{array}{l}\text { Relatief jong } \\
\text { polderlandschap met } \\
\text { dijken, randmeren, } \\
\text { IJsselmeer, duinen }\end{array}$ & $\begin{array}{l}\text { Noordoostpolder: 1:4 } \\
\text { pootaardappel - } \\
\text { zomergerst/zaaiui - suikerbiet - } \\
\text { wintertarwe; } \\
\text { Flevopolders: } 1: 4 \\
\text { consumptieaardappel - } \\
\text { zomergerst/zaaiui - suikerbiet - } \\
\text { wintertarwe }\end{array}$ \\
\hline $\begin{array}{l}\text { Zuidwestelijk } \\
\text { kleigebied }\end{array}$ & Klei / zavel & $\begin{array}{l}\text { Eiland en } \\
\text { polderlandschap met } \\
\text { dijken, kwelders, } \\
\text { kleinere aaneengesloten } \\
\text { teeltgebieden }\end{array}$ & $\begin{array}{l}\text { 1:4 consumptieaardappel - } \\
\text { graszaad/zaaiui - suikerbiet - } \\
\text { wintertarwe }\end{array}$ \\
\hline Veenkoloniën & Zandgrond / dalgrond & $\begin{array}{l}\text { Grootschalig } \\
\text { ontginningsgebied met } \\
\text { kanalen en 'monden', } \\
\text { lintbebouwing }\end{array}$ & $\begin{array}{l}\text { 1:2 zetmeelaardappel - } \\
\text { zomergerst/wintertarwe - } \\
\text { zetmeelaardappel - suikerbiet }\end{array}$ \\
\hline $\begin{array}{l}\text { Noordelijke zand- en } \\
\text { dalgronden }\end{array}$ & Zandgrond / dalgrond & $\begin{array}{l}\text { 'Brinklandschap' met } \\
\text { structuren vanuit dorp } \\
\text { gedacht, relatief } \\
\text { kleinschalig, ook bos }\end{array}$ & $\begin{array}{l}\text { Consumptie-/ zetmeelaardappel - } \\
\text { zomergerst - suikerbiet - } \\
\text { wintertarwe }\end{array}$ \\
\hline $\begin{array}{l}\text { Oostelijke } \\
\text { zandgebieden }\end{array}$ & Zandgrond & $\begin{array}{l}\text { 'Brinklandschap' met } \\
\text { structuren vanuit dorp } \\
\text { gedacht, ook bos }\end{array}$ & $\begin{array}{l}\text { 1:4 consumptieaardappel - } \\
\text { zomergerst - suikerbiet - } \\
\text { wintertarwe }\end{array}$ \\
\hline Rivierkleigebied & Rivierklei & $\begin{array}{l}\text { Open landschap met de } \\
\text { rivieren als sterk } \\
\text { beeldbepalend, } \\
\text { uiterwaarden }\end{array}$ & $\begin{array}{l}1: 4 \text { consumptieaardappel - } \\
\text { zomergerst - suikerbiet - } \\
\text { wintertarwe }\end{array}$ \\
\hline $\begin{array}{l}\text { Zuidelijke } \\
\text { zandgebieden en } \\
\text { löss }\end{array}$ & Zandgrond / löss & $\begin{array}{l}\text { Peel- en } \\
\text { Heuvelruglandschap, } \\
\text { deels vlak } \\
\text { ontginningsgebied, } \\
\text { deels heuvelachtig }\end{array}$ & $\begin{array}{l}1: 4 \text { consumptieaardappel - } \\
\text { zomergerst - suikerbiet - } \\
\text { wintertarwe }\end{array}$ \\
\hline
\end{tabular}

Bovenstaande is in het kader van deze studie over klimaatverandering noodzakelijk om duidelijk in beeld te hebben, om bij de verdere uitwerking van adaptatiemaatregelen juiste keuzes te kunnen maken.

De combinatie van klimaateffecten per regio, grondsoort en gewas geeft een beeld waar de kwetsbaarheden van de Nederlandse akkerbouwsector zitten, of mogelijk in de toekomst gaan ontstaan. Voor het benoemen van deze kwetsbaarheden wordt eveneens gebruik gemaakt van de vier klimaattrends van de Nationale Adaptatie Strategie.

De klimaattrend "Het wordt warmer"

Hoewel het landelijk gezien warmer wordt, is dit effect verder landinwaarts groter, zoals in de vorige paragraaf (1.2) beschreven. Met name het gebied in Zuidoost-Nederland zal hier het sterkst mee te maken krijgen. In dit gebied zullen op basis van het bouwplan uit bovenstaande tabel met name 
consumptieaardappelen hier het meest kwetsbaar voor zijn. De toename van hittegolven kan zorgen voor extra schade als gevolg van doorwas en aanzienlijke opbrengstreductie wanneer de aardappelplant afsterft door hoge verdamping en verbranding (Schaap, Blom-Zandstra, Hermans, Meerburg, \& Verhagen, 2011). Warmte (met name in combinatie met vochtig weer) zorgt daarnaast voor een snellere verspreiding van ziekteverwekkers zoals bacterieziekte Erwinia. Voor granen en suikerbieten zijn de consequenties van de trend "het wordt warmer" minder groot. Bij suikerbieten kunnen hoge temperaturen ten koste gaan van de suikerproductie, maar het negatieve effect op de opbrengst is veel minder groot dan bij consumptieaardappelen (Bijker \& Verstand, 2020; Daan Verstand et al., 2020). Granen, en met name wintergranen hebben een teeltperiode die wat eerder in het jaar ligt. Een hittegolf midden in de zomer zal bij deze gewassen daarom minder negatieve gevolgen hebben. Daarnaast is het financiële saldo van granen natuurlijk veel lager dan aardappelen. Eenzelfde procentuele lagere opbrengst bij aardappelen heeft een veel grotere impact heeft dan eenzelfde opbrengstverlies bij graan. De trend "het wordt warmer" heeft niet alleen negatieve effecten. Zo zorgt het er ook voor dat het groeiseizoen eerder kan beginnen en dat de groei sneller kan verlopen. Daarnaast neemt de kans op nachtvorst in het voorjaar af, dat bijvoorbeeld voor de teelt van suikerbieten een positieve invloed heeft (Geijzendorffer et al., 2011).

Naar verwachting zullen door klimaatverandering nieuwe ziekten en plagen geïntroduceerd worden. Op dit moment is nog onvoldoende duidelijk of en in welke mate de gewassen hiervan impact zullen ondervinden. Tevens kan de frequentie van optreden van ziekten en plagen veranderen doordat de weersomstandigheden waarin deze gedijen beïnvloed wordt. In hoofdstuk 0 is een nadere uitwerking van de effecten van ziekten en plagen als gevolg van klimaatverandering op gewasniveau te vinden.

\section{De klimaattrend "Het wordt natter"}

Zoals in de vorige paragraaf beschreven, wordt het landelijk gezien natter, een trend die al langer gaande is. Hier hebben alle regio's in Nederland mee te maken. De impact zal echter verschillend zijn, afhankelijk van gewas en grondsoort. De toename van de neerslagsom geldt voor alle seizoenen, met uitzondering van de zomer. Wel nemen ook in de zomer de extremen toe; grotere kans op veel neerslag in een korte periode. De kans op extremen neemt, zoals in de vorige paragraaf beschreven, met name in de kustprovincies toe. Klei- en veengronden zijn extra gevoelig voor vernatting en daarmee schade voor het gewas. Bij zandgronden is de impact hiervan minder groot, door de grotere doorlatendheid. De combinatie van een risicovol gewas in combinatie met kwetsbare grondsoort en ligging in de kustregio geeft hierbij uiteraard de hoogste schadekans. Uit de belangrijkste gewassen zoals in bovenstaande bouwplannen per regio genoemd, zijn aardappelen het meest kwetsbaar vanwege het rotten van de knollen. De impact van overvloedige neerslag bij tarwe of suikerbieten ligt veel lager (Daan Verstand et al., 2020; Wit de, Swart, \& Luijendijk, 2009).

\section{De klimaattrend "Het wordt droger"}

De zomers van 2018 en 2019 hebben het effect van deze trend goed zichtbaar gemaakt. De zomerperiode wordt droger. Regionaal ontstaan grote verschillen in de gewasgroei, vooral afhankelijk van de beschikbaarheid van zoet water om te beregenen. In sommige waterschap gebieden gold een beregeningsverbod vanuit oppervlaktewater, zoals in Hunze en Aa's en Limburg, maar ook een verbod van grondwater zoals in regio Vechtstromen en Rijn en IJssel (Boerderij, 2018). Zonder beregeningsmogelijkheid, kunnen gewassen enorme opbrengstschades laten zien. Kapitaalintensieve gewassen zoals aardappelen en uien hebben in een deel van Zuidwest-Nederland waar beregening niet mogelijk is, geleid tot schades van meer dan $50 \%$ (van Hussen, van de Velde, Läkamp, \& van der Kooij, 2019). Tevens kan in consumptieaardappelen schade optreden door Alternaria, dat optreedt bij droge omstandigheden (persoonlijke communicatie Harm de Boer, 2020). Ook de zetmeelaardappelteelt in de Veenkoloniën is in dit opzicht kwetsbaar omdat zoetwater in dit gebied vanwege de ligging ver van rivieren en het IJsselmeer, lastig beschikbaar gemaakt kan worden. In tegenstelling tot gewassen waar een lagere opbrengst door een hogere marktprijs (deels) gecompenseerd kan worden, wordt een lagere gewasopbrengst bij zetmeelaardappelen niet of nauwelijks in de marktprijs gecompenseerd.

In tegenstelling tot wateroverlast, waar heftige buien vaak een meer lokaal karakter hebben, is dit een trend die, wanneer het zich voordoet, veel grotere gebieden raakt. De kwetsbaarheid is met name gelegen in de combinatie grondsoort (klei/zand), ligging (kust/binnenland), soort gewas en de mogelijkheden die er zijn om te beregenen. Deze complexe samenhang van diverse factoren maakt 
dat het lastiger om per teeltgebied de gevoeligheid te bepalen. Het mag duidelijk zijn dat de combinatie van de diverse factoren (zandgrond, binnenland, droogtegevoelig gewas, geen beregeningsmogelijkheden) zorgt voor een sterk verhoogd droogterisico en wellicht in de toekomst kan leiden tot het verdwijnen van bepaalde teelten.

De klimaattrend "De zeespiegel stijgt"

Door de stijging van de zeespiegel neemt de verzilting, in met name de kustregio, verder toe. Direct aan de kust vindt er indringing van zout zeewater plaats op plekken waar de zee hoger staat dan het land (denk aan polders onder NAP). Omdat zoetwater lichter is dan zout water, vormen zich in deze gebieden zoetwaterlenzen bovenop het zoute grondwater. De voorraad zoetwater is daarom zeer beperkt en mogelijkheden voor beregenen zijn daarom klein of niet aanwezig. Klimaatverandering zorgt ervoor dat de hoeveelheid zoetwater nog kleiner wordt, omdat het neerslagoverschot kleiner kan worden tijdens het groeiseizoen en er bij droge en warme omstandigheden meer water verdampt. Een uitgebreide beschrijving van oorzaken en gevolgen is te vinden in Verstand et al (2020). Voor de akkerbouw is dit probleem het grootst op het Noordelijk Kleigebied en in delen van het Zuidwestelijk kleigebied.

Gewassen reageren verschillend op een toename van het zoutgehalte in het water. Figuur 13 (Van Bakel, Kselik, Roest, \& Smit, 2009) toont schematisch hoe deze relatie eruit ziet. Er is een drempelwaarde (de zouttolerantiedrempel genoemd, in de figuur threshold). Als het zoutgehalte boven dit niveau komt, gaat er gewasschade optreden. Deze gewasschade loopt op met een toenemend zoutgehalte van het water. Hoe sterkt de schade toeneemt (de zoutschadegevoeligheid), verschilt ook per gewas.

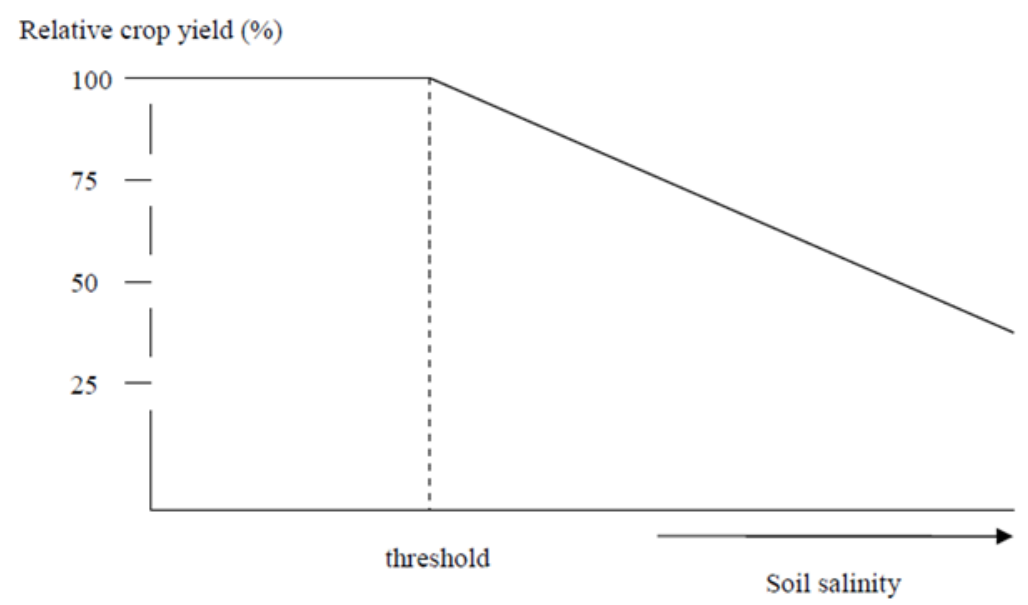

Figuur 13. Schematische weergave van de zout-schade relatie (Van Bakel et al., 2009).

Het zoutgehalte wordt uitgedrukt in EC of in mg/liter. Voor beide geldt, hoe hoger, hoe zouter. Hier gebruiken we voornamelijk mg/liter. Om van mg/liter naar EC te gaan, geldt de volgende formule (van Bakel et al., 2018):

\section{Van zoutconcentratie naar EC: $E C=1 / 400 c(\mathrm{mg} / \mathrm{L})$}

De grens tussen zoet en brak grondwater wordt bereikt wanneer er een overschrijding is van $1000 \mathrm{mg}$ $\mathrm{Cl}$ per liter. Van zoutwater is sprake als de grens van $3000 \mathrm{mg} \mathrm{Cl}$ per liter wordt overschreden. Hierbij wordt aangesloten bij de definitie die Deltares geeft over landbouwkundig zoet, brak en zout water in (Oude Essink \& Van Baaren, 2009).

De effecten van zoutwater dat bij de wortels van een gewas komt zijn tweeledig (Stuyt, BlomZandstra, \& Kselik, 2016): 
- Reductie van wateropname van gewassen. De plant moet harder zijn best doen om water uit de bodem te krijgen, waardoor de huidmondjes zich eerder sluiten. Een vergelijkbaar effect treedt op bij droogte. Hierdoor zal opbrengstderving optreden.

- Toxische werking. De groeisnelheid van de plant neemt af, omdat natrium (zout) de fotosynthese kan remmen.

Daarnaast kan beregening met zilt/zout water leiden tot bladverbranding (Polman, Linderhof, Michels, van der Sandt, \& Vogelzang, 2012). Verzilting van het water op kleigrond heeft ook zijn effect op de structuur van de bodem. De kleigrond wordt namelijk meer slempgevoelig, waardoor de bodem bij natte situaties minder goed water door zullen laten. Hierdoor kan er in het gewas natschade optreden. Bij drogere omstandigheden wordt een slempgrond keihard, wat ook negatief uit kan pakken voor het gewas (Stuyt et al., 2016).

Van de belangrijkste akkerbouwgewassen zijn met name aardappelen, uien en peen het meest kwetsbaar voor een hoger zoutgehalte. Een hoger zoutgehalte in het water zal bij deze gewassen daarom snel tot opbrengstreductie leiden. Granen en suikerbieten zijn meer zout-tolerant. De volgende figuur (Figuur 14) laat zien dat er sprake is van opbrengstderving bij alle gewassen bij toename van de zoutconcentratie in het water. Afhankelijk van het gewas treedt dit snel of minder snel op. Verzilting zorgt ervoor dat de grens tussen zoet en brak wordt overschreden omdat het zoute grondwater bij de wortels van de plant komt. Afhankelijk van de mate van verzilting (ernstig of minder ernstig) neemt de zoutconcentratie verder toe. Onderstaande Figuur 14 visualiseert dit voor een aantal belangrijke landbouwgewassen (PBL, 2012; Roest, Bakel, \& Smit, 2003). Daar waar de lijn van een gewas(groep) de $\mathrm{x}$-as raakt, is de zouttolerantiedrempel.

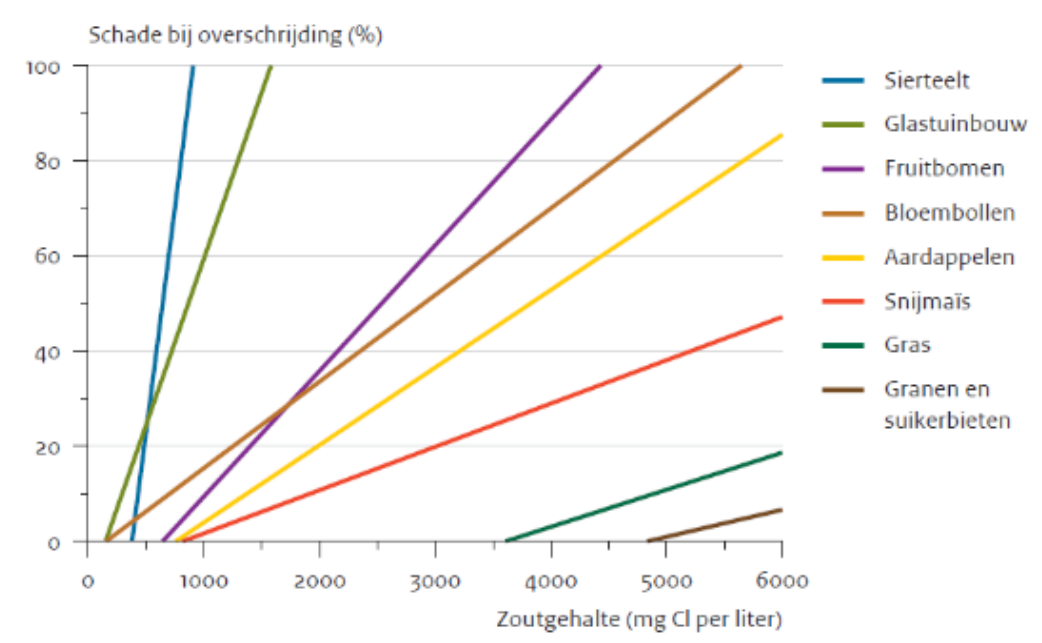

Figuur 14; Relatie tussen zoutgehalte en opbrengstschade aan landbouwgewassen. Bron: PBL 2012).

Er wordt vaak echter een range aangegeven van de zouttolerantiedrempel van een gewas, in plaats van één harde waarde. De zouttolerantiedrempel verschilt namelijk per gewasstadium en de grondsoort (Stuyt et al., 2016). Daarnaast verschilt de zouttolerantie sterk tussen irrigatiewater en bodemwater. De zouttolerantiedrempels voor irrigatiewater liggen veel lager dan voor verzilting van onder uit de bodem (Van Bakel et al., 2009). Bij irrigatiewater kan er namelijk ook nog verbranding van het blad optreden (Stuyt et al., 2016) (persoonlijke communicatie G. Blom 2020).

Stuyt en collega's (Stuyt et al., 2016) hebben in een studie bestaande zouttoleranties voor irrigatiewater geïnventariseerd en geanalyseerd met statistische analyse (standaard normale kansverdeling) om de waarschijnlijke drempelwaarde vast te stellen, binnen het betrouwbaarheidsinterval van 40\%. Voor verdere uitleg, zie (Stuyt et al., 2016). Per gewas komen de volgende figuren eruit, die ingaan op de bandbreedte en de meest waarschijnlijke zouttolerantiedrempels voor de relevante akkerbouwgewassen Figuur 15. 

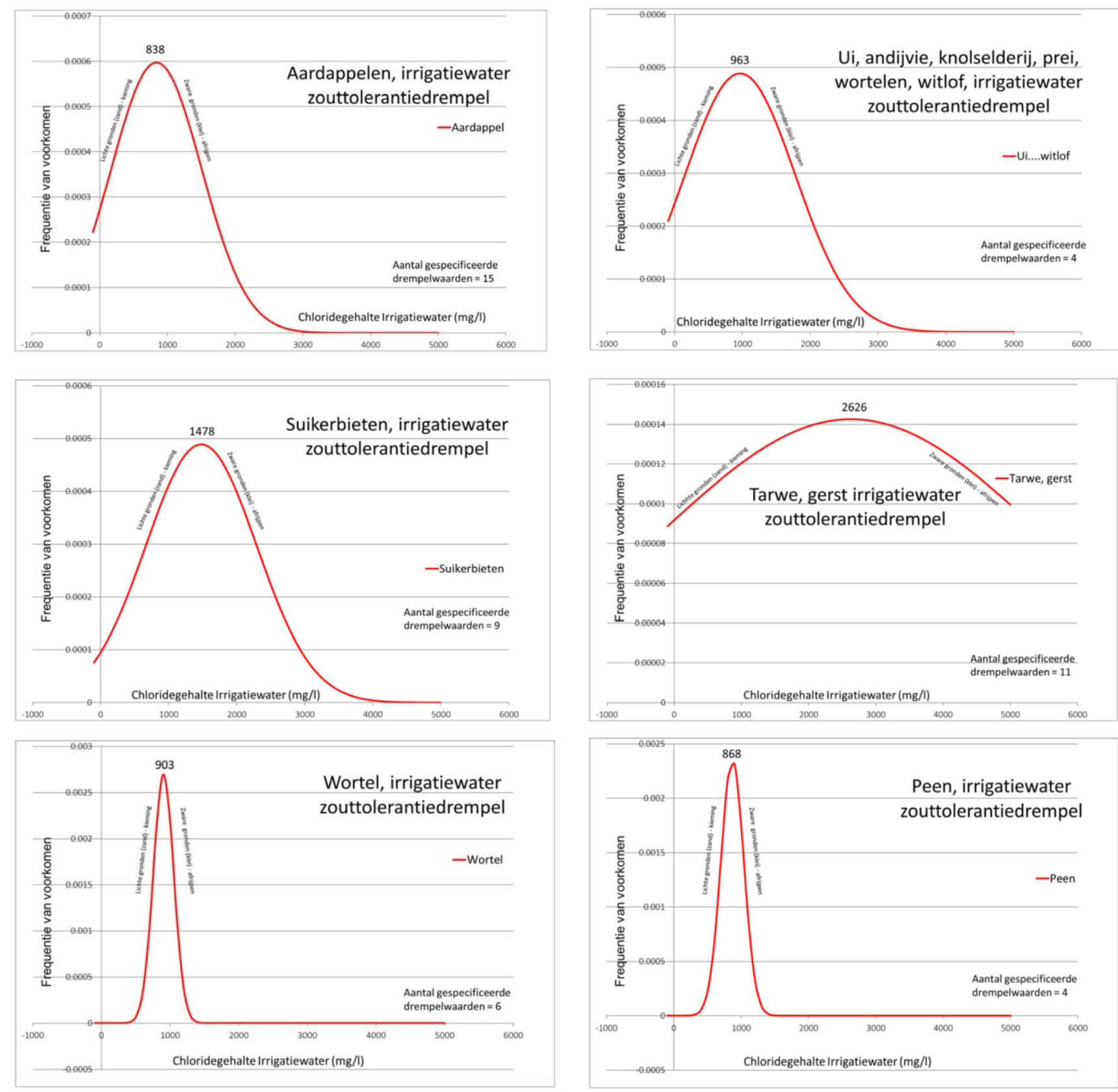

Figuur 15. figuren van zouttolerantiedrempels per gewas voor irrigatiewater, met de meest waarschijnlijke waarde op de top van de grafiek. Een steilere curve betekend een zekerdere waarde (Stuyt et al., 2016).

In de figuren is te zien aardappelen de laagste waarschijnlijke zouttolerantiedrempel $(838 \mathrm{mg} / \mathrm{l})$ heeft van de geselecteerde gewassen. De drempel is nog lager op zandgronden en tijdens de kieming van de planten. Dat geldt ook voor de andere gewassen. Gewassen op kleigronden en tijdens de afrijpingsperiode vormen minder kwetsbare situaties, waardoor de drempelwaarde dan hoger ligt. Op zandgronden is het zout direct bedreigend voor de wortels, terwijl op kleigrond de geladen deeltjes het zout (natrium) nog kunnen binden, waardoor licht zout water minder bedreigend is.

De grafiek voor tarwe is erg vlak in vergelijking met de andere gewassen. Dat komt omdat de onderliggende zouttolerantiedrempels in de analyse sterk verschillen; de spreiding is groot (Stuyt et al., 2016).

Tijdens droogte is er behoefte aan irrigatie. Soms is het irrigatiewater echter verzilt. De studie van van Bakel (2009) meldt dat het uitgebreid beregenen met (licht) zout water minder schade tot gevolg heeft dan de gewasschade die op zou treden door de droogte, zonder de beregening. Het kantelpunt 
tussen beregenen met zout water en droogteschade (voor droog jaar 1974, zie (Van Bakel et al., 2009) ligt voor aardappels op kleigrond rond de $1750 \mathrm{mg} / \mathrm{l}$ zout concentratie. Dat betekend dat als het beregeningswater een lagere waarde van $1750 \mathrm{mg} / \mathrm{l}$ heeft, rijkelijk beregenen met dit water in minder schade resulteert dan de schade die op zou treden door de droogte (zonder beregenen). Voor suikerbiet ligt deze waarde op 5000 mg/l (Van Bakel et al., 2009). Uiteraard geldt dat als de droogte minder hevig uitpakt, het kantelpunt wat betreft zoutgehalte lager ligt.

Braam (2018) presenteert vergelijkbare resultaten, maar dan voor bloembollen; beregening met water met zoutwaardes tussen $1500-2500 \mathrm{mg} / \mathrm{l}$ leiden tot minder schade dan de schade die op zou treden zonder beregening als gevolg van droogte. Het voordeel van beregenen is dan dus groter dan de te verwachten zoutschade. Tevens is het belangrijk om bij beregening met zilt water, voldoende hoeveelheid te geven, zodat ophoping van zout minder op zal treden (Braam, 2018).

Normaal gesproken valt er in de winter voldoende neerslag om opgehoopt zout door verzilting of vanuit beregening weg te spoelen, zodat er het jaar erna geen effecten van het zoute water merkbaar zullen zijn (Van Bakel et al., 2009). 


\section{$2 \quad$ Verdieping kwetsbaarheden per gewas}

In dit hoofdstuk worden de kwetsbaarheden per gewas voor specifieke weersomstandigheden waarvan het voorkomen door klimaatverandering wordt beïnvloed, beschreven. Dat bouwt voort op de bovenstaande genoemde inzichten en de Agroklimaatkalender. De resultaten voor vijf geanalyseerde akkerbouwgewassen worden hier gepresenteerd. In eerder verschenen (Bijker \& Verstand, 2020; Daan Verstand et al., 2020) worden deze effecten al genoemd op basis van de Agroklimaatkalender. Hieronder worden deze effecten nader verdiept, in detail toegelicht en waar nodig uitgebreid. Dat is gedaan voor de vijf gewassen die ook naar voren kwamen uit de analyse in 1.3.

\section{Methodiek}

De effecten van klimaatverandering en weersextremen voor de gewassen aardappel, zaaiui, peen, wintertarwe en suikerbiet zijn voor de verschillende klimaatscenario's in kaart gebracht door een tweetal type bronnen te raadplegen: een systematisch literatuuronderzoek en aanvulling en inzichten vanuit expertkennis. Het systematisch literatuuronderzoek onderzoek is uitgevoerd met betrekking tot de kwetsbaarheden van de geselecteerde gewassen ten opzichte van specifieke weersomstandigheden en bijkomende klimaatverandering. Hiervoor zijn agronomische, economische en klimatologische wetenschappelijke artikelen geselecteerd met behulp van zoekwoorden als 'climate or weather' en 'extreme' of 'change' en '(economic) effects' en 'The Netherlands or Europe', in combinatie met het specifieke gewas en daarnaast uitgevoerd in het Nederlands. Voor deze zoekopdrachten zijn de zoekmachines Google scholar en onlinebibliotheek van Wageningen University \& Research gebruikt. Daarnaast zijn teelthandleidingen van de gewassen geraadpleegd om inzicht te krijgen in de agronomische effecten van de verandering van klimaatvariabelen neerslag en temperatuur op het gewas gedurende het teeltseizoen, zoals de groei en ontwikkeling van het gewas, grondbewerking, ziekten en plagen en vruchtopvolging. Deze effecten van zijn vervolgens opgedeeld in effecten (1) op kwaliteit en fysieke opbrengsten en (2) ziekten en plagen, zoals ook is gedaan in (Haverkort \& Verhagen (2008). Om de meest relevante en representatieve effecten te selecteren voor de Nederlandse situatie is doormiddel vanuit expertkennis een selectie gemaakt van effecten. Hierbij is gebruik gemaakt van een lijst met effecten op basis van het literatuuronderzoek. Daarnaast zijn er eventuele missende effecten aangevuld welke in praktijk gezien worden of mogelijk een rol kunnen aan spelen. De verwachte effecten van klimaatverandering in dit onderzoek zijn gebaseerd op de klimaatscenario's afkomstig van het KNMI (Klein Tank et al., 2014).

\section{$2.1 \quad$ Aardappel}

\subsubsection{Effecten klimaatverandering op kwaliteit en fysieke opbrengsten}

De teelthandleiding (Bus, Van Loon, \& Veerman, 2003) geeft aan dat het tijdstip van de hoofdgrondbewerking voor de teelt is afhankelijk van de grondsoort. Op klei- en zavelgronden wordt deze vaak voor de winter uitgevoerd en op zand- en dalgronden tussen maart en april. Het is van belang dat dit niet onder te natte omstandigheden plaatsvindt, omdat dit anders kan leiden tot versmering, verdichting, kluitvorming en verslemping (Bus et al., 2003). De klimaatscenario's laten een toename zien van de hoeveelheid neerslag in het voor- en najaar waardoor het aantal gunstige momenten om de grondbewerking uit te voeren daalt. Een verlate pootdatum kan volgens Van Oort, Timmermans, Meinke, \& Van Ittersum (2012) het groeiseizoen verkorten doordat de omstandigheden later in het seizoen vaak te nat zijn om te oogsten. Volgens D. Van Balen (persoonlijke communicatie, 8 maart 2021) kan de Phytophthora infestans druk hoger zijn later in het seizoen. Wanneer de ziekte minder goed of niet beheersbaar is (biologisch landbouwsysteem) zal het gewas eerder afsterven en kost dat opbrengst, daarom heeft een vroege pootdatum de voorkeur mits de bodemgesteldheid dit toelaat. De klimaatscenario's laten zowel in het najaar, winter als het voorjaar een stijging van de 
hoeveelheid neerslag zien waardoor de mogelijke momenten om de grondbewerking uit te voeren dalen. Uit de teelthandleidingen (Bus et al., 2003; Van Loon \& Veerman, 1993; Veerman, 2003) komt naar voren dat hogere temperaturen de kieming bevorderen met daaropvolgend een snellere wortelgroei en versnelde opkomst. Voor de loof- en knolgroei zijn temperatuur, ras en water in een belangrijke mate bepalend voor de groei. Voor de fotosynthese is het van belang dat er voldoende water beschikbaar is voor de gewasgroei. Daarnaast bevorderen temperaturen tussen 20 en $25^{\circ} \mathrm{C}$ de fotosynthese. De fotosynthese neemt af bij hoge temperaturen (boven de $30^{\circ} \mathrm{C}$ ) waardoor er minder waardoor er minder koolhydraten worden omgezet in zetmeel. Een belangrijk effect wat hiervan is dat de potentiële knolopbrengst afneemt (Bus et al., 2003; Van Loon \& Veerman, 1993; Veerman, 2003). Voor de knolopbrengst is het van belang dat de moederknol goed kiemt, optimaal hiervoor is bodemtemperatuur van minimaal 7 à 8 graden in een vochtige grond (Van Loon \& Veerman, 1993). Bij een lange periode van hoge temperaturen kunnen door een warme bodem de aangelegde knollen gaan kiemen (doorwas) (Bodlaender, Lugt, \& Marinus, 1964). Doorwas betekent dat er een tweede generatie knollen wordt gevormd, de secundaire knollen (Bodlaender et al., 1964). Deze secundaire knollen groeien vervolgens door het zetmeel te onttrekken van de primaire knollen. Dit resulteert in zogenaamde glazige knollen waardoor de kwaliteit van de primaire knollen sterk afneemt (Bus et al., 2003; Van Loon, 1981; Van Loon \& Veerman, 1993). De hiervoor beschreven omstandigheden met droogte in de zomer en hoge temperaturen zullen volgens de klimaatscenario's in de toekomst door een afname van neerslag en gemiddelde stijgende temperaturen vaker manifesteren. In de toekomst neemt in september en oktober de hoeveelheid neerslag en de maximum uur neerslag per jaar toe, zoals eerder al te zien was in onder andere Figuur 5 . Het laatste houdt in dat buien in de toekomst onder de klimaatscenario's extremer worden. Hierdoor neemt de kans toe dat percelen langdurig onder water komen te staan en dat er rot optreedt (D. Van Balen, persoonlijke communicatie, 12 november 2020). De klimaatscenario's laten zien dat de neerslag hoeveelheid in het najaar toeneemt, waardoor mogelijk oogstwerkzaamheden vaker plaats zullen vinden onder natte omstandigheden. Hierdoor kunnen knollen makkelijker worden beschadigd en worden infecties eenvoudiger verspreid (Bus et al., 2003). Tevens leidt een toename van de neerslag in het najaar en winter tot een verhoogde denitrificatie (D. Van Balen, persoonlijke communicatie, 12 november 2020) wat ten koste gaat van een efficiënte benutting van meststoffen (Aulakh, Doran, \& Mosier, 1992). Naast de hiervoor beschreven verandering klimaatvariabelen temperatuur en neerslag, neemt ook de CO2-concentratie in de atmosfeer toe (Klein Tank et al., 2014). Uit het onderzoek door Schapendonk, Pot, \& Goudriaan (1995) komt naar voren dat een toename van de CO2-concentratie een gunstig effect heeft op de droge stof productie en dat hierdoor de knollenopbrengst van aardappelen toeneemt.

\subsubsection{Effecten klimaatverandering op ziekten en plagen}

Uit de studie door Haverkort \& Verhagen (Haverkort \& Verhagen, 2008) komt naar voren dat door hogere temperaturen gedurende het groeiseizoen de effecten van ziekten en plagen kunnen toenemen doordat deze zich eenvoudiger kunnen vermeerderen bij hogere temperaturen. Daarbij kunnen ziekten en plagen zich ook vaker vermeerderen doordat het groeiseizoen wordt verlengd. Volgens Veerman (Veerman, 2003) kan aardappelopslag namelijk in opvolgende teelten een risico vormen. Door aardappelopslag kunnen veel ziektes die bij de aardappelteelt een rol spelen zich in stand houden en verspreiden. Dit is bijvoorbeeld aan de orde bij aardappelcysteaaltjes, Phoma en Rhizoctonia. Phytophthora infestans kan bij nat weer eenvoudig via het blad de plant binnendringen en kan binnen enkele weken een heel perceel infecteren (Haverkort, Struik, Visser, \& Jacobsen, 2009). Volgens D. Van Balen (persoonlijke communicatie, 8 maart 2021) loopt de teler een verhoogd risico dat $P$. infestans voorkomt en dat er aardappelplanten worden besmet. Ook kunnen natte omstandigheden ervoor zorgen dat niet alleen het blad wordt geïnfecteerd, maar ook de knollen. Hevige neerslag kan het inspoelen van sporen tot gevolg hebben welke de knol kunnen infecteren. Dit is niet altijd direct zichtbaar en kan later in de bewaring voor problemen zorgen (rotte knollen). Niet alleen is er dan sprake van opbrengstverlies maar ook van hogere bewaarkosten omdat er meer gedroogd (geventileerd) moet worden. Door de toename van de frequentie droge periodes kan $P$. infestans mogelijk beter worden bestreden.

Insecten kunnen zich door de hogere temperaturen vaker per seizoen voortplanten (Yamamura \& Kiritani, 1998). De Coloradokever overwintert in de grond en kan samen met de uitgekomen larven door het vreten aan de bladeren voor grote schade zorgen (Van Loon \& Veerman, 1993). Volgens D. 
Van Balen (persoonlijke communicatie, 8 maart 2021) kunnen de zachtere winters en de hogere temperaturen in het groeiseizoen ervoor zorgen dat de Coloradokever makkelijker kan overwinteren en daarnaast meer generaties kan vormen. Tegen kevers en larven in een aardappelperceel kan gericht gespoten worden. Zachte winters dragen er ook aan bij dat luizen onder gunstigere omstandigheden kunnen overwinteren (D. Van Balen, persoonlijke communicatie, 12 november 2020), waardoor ze een belangrijke rol kunnen spelen in virusoverdracht (Veerman, 2003). Door toename van droge periodes on de klimaatscenario's in de zomer kan gewone schurft en poederschurft voor meer opbrengstverlies zorgen (Veerman, 2003).

De toekomstige toename van temperaturen en onregelmatigere neerslag kunnen ook mogelijk meer problemen ontstaan rondom bacterieziektes. Tijdens een warme en natte periode kunnen namelijk verschillende bacterieziekten de aardappelplant aantasten: bruinrot, natrot, en zwartbenigheid (Veerman, 2003). Natrot en bruinrot worden veroorzaakt door het bacteriën van het geslacht Erwinia (Dickeya en Pectobacterium (Toth et al., 2011). Deze ziektes zijn zeer besmettelijk en kunnen via verschillende bronnen de aardappelplant infecteren, zoals de overblijfsels van planten (andere gewassen of onkruid), natte omstandigheden, insecten, mechanisatie (Toth et al., 2011). Om verspreiding van bruinrot tegen te gaan geldt in Nederland voor bepaalde gebieden een verbod op het gebruik van oppervlaktewater bij de teelt van consumptieaardappelen en er geldt een landelijk verbod bij de teelt van pootaardappelen (NVWA, n.d.).

\section{$2.2 \quad$ Zaaiui}

\subsubsection{Effecten klimaatverandering op kwaliteit en fysieke opbrengsten}

Uit de teelthandleiding door De Visser \& Zwanepol (1993) blijkt dat de ontwikkeling en de groei van zaaiui afhankelijk is van verschillende factoren. Het tijdstip van de hoofdgrondbewerking hangt mede af van de weersomstandigheden. Een te fijn verkruimeld zaaibed omstandigheden verhoogt het risico op verslemping van de bodem en korstvorming. Volgens D. Van Balen (persoonlijke communicatie, 12 november 2020) kunnen droge omstandigheden in het voorjaar bijdragen aan een verminderde werking van bodemherbiciden waardoor de onkruiddruk kan toenemen. Daartegen kan grondbewerking onder te natte omstandigheden de kans op groeiafwijkingen aan de ui toenemen en waardoor er geen goed verkruimeld zaaibed worden gerealiseerd. Onder de klimaatscenario's stijgt de hoeveelheid neerslag in maart en april en neemt mogelijk de kans op ongunstige omstandigheden voor het uitvoeren van de grondbewerking toe.

Uit de teelthandleiding (Van den Broek, 2003) komt naar voren dat zaaiuien bij lage temperaturen tussen $7^{\circ} \mathrm{C}-13^{\circ} \mathrm{C}$ in eind mei de ui tot bloei kan komen wat ten koste gaat van fysieke opbrengst, kwaliteit, oogst en bewaarbaarheid. Uit de klimaatscenario's blijkt dat door klimaatverandering de temperatuur in het voorjaar en de zomer stijging wat de bolvorming bevordert en de kans op bloei doet afnemen. In de zomer kunnen door de hogere temperaturen en kans op droogte vaker problemen optreden. Van den Broek (Van den Broek, 2003) geeft aan dat uien door het oppervlakkige en schaarse bewortelingspatroon gevoelig zijn door droogte. Bij een beperkt vochttekort sluiten de huidmondjes zich, dit zorgt ervoor dat het gewas de droogte goed kan doorstaan maar dit gaat ten koste van de opbrengst. Uit de analyse naar de effecten van de droogte in 2018 blijkt dat uien ten opzichte van andere gangbare akkerbouwgewassen de grootste schade leden, tot wel 50\% ten opzichte van het voortschrijdende gemiddelde (Stokkers, Prins, Meer, \& Jager, 2018). Daarnaast kan een periode van hevige neerslag tot grote schade leiden en de oogst geheel doen mislukken (Van den

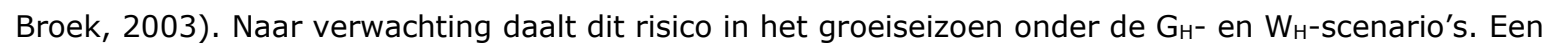
vroege oogst bij droge omstandigheden is van belang voor de kwaliteit van de ui, omdat anders de kans groter is dat huiden gaan verweren en dat rooien onder natte omstandigheden versmering veroorzaakt (Van den Broek, 2003). Uit de klimaatscenario's blijkt dat de verwachte neerslag toeneemt in augustus in het $\mathrm{G}_{\mathrm{L}}$-scenario en in september in het $\mathrm{G}_{\mathrm{L}}$ - en $\mathrm{G}_{\mathrm{H}}$-scenario. Uit onderzoek van Wurr e.a. (1998) komt naar voren dat de toename van de CO2-concentratie in de atmosfeer een positieve invloed heeft op de fysieke opbrengsten van uien. 


\subsubsection{Effecten klimaatverandering op ziekten en plagen}

Verschillende ziekten en plagen kunnen bepalend zijn voor de opbrengsten en kwaliteit van uien. Volgens D. Van Balen (persoonlijke communicatie, 12 november 2020) kan de schimmel Fusarium door een toenemend aantal droogtes vaker de uit aantasten en rot veroorzaken. Ook de schimmel Valse meeldauw zal naar verwachting meer problemen geven wanneer er niet op tijd beregend kan worden onder voornamelijk droge omstandigheden waardoor de groei stagneert. Volgens Porter, Parry, \& Carter (1991) kan klimaatverandering een significant effect hebben op de ontwikkeling en verspreiding van insecten. Uit het onderzoek komt naar voren dat door het veranderende klimaat er een verandering op kan treden van de geografische spreiding van insecten. Ook kunnen er meer problemen zijn rondom een toename in overwintering en het aantal generaties per seizoen door een langere periode van gunstige temperaturen. Daarnaast kunnen er meer problemen ontstaan door invasieve soorten. Naar verwachting zullen de hogere temperaturen ook bevorderlijk zijn voor de tabakstrips (Bergant, Trdan, Žnidarčič, Črepinšek, \& Kajfež-Bogataj, 2005; De Visser \& Zwanepol, 1993).

\subsection{Peen}

\subsubsection{Effecten klimaatverandering op kwaliteit en fysieke opbrengsten}

Voor de teelt van de peen is het van belang dat deze plaatsvindt op een lichte bouwvoor die geen slemp- of korstvorming vertoond, goed bewortelbaar is en een vochtvoorziening die tijdens het seizoen voldoende is waardoor het gewas vlot kiemt en goed wortelt (Buishand, 1981). In het begin van het seizoen is het noodzakelijk dat de grondbewerking niet plaatsvindt met een te natte bodem omdat dit anders tot bodemverdichting kan leiden (Buishand, 1981). Sukkel, Van Leeuwen-Haagsma, Van Balen \& Holswerda (2004) stellen dat bodemverdichting voor kwaliteitsproblemen kunnen zorgen zoals vertakte, kromme en korte peen. Om deze reden is een goede ontwatering van belang. De klimaatscenario's laten zien dat in het voorjaar de verwachte hoeveelheid neerslag toeneemt. In de zomer laten de $\mathrm{G}_{\mathrm{L}}$ - en $\mathrm{W}_{\mathrm{L}}$-scenario's een licht stijgende neerslaghoeveelheid zien, de $\mathrm{G}_{\mathrm{H}^{-}}$en $\mathrm{W}_{\mathrm{H}^{-}}$ scenario's laten daarentegen een daling zien. Mogelijk verbeteren onder de $\mathrm{G}_{\mathrm{H}^{-}}$en $\mathrm{W}_{\mathrm{H}}$-scenario's de omstandigheden om te zaaien in vergelijking met de $\mathrm{G}_{\mathrm{L}}$ - en $\mathrm{W}_{\mathrm{L}}$-scenario's, maar kunnen er problemen ontstaan wanneer er niet voldoende mogelijkheden zijn om te beregenen. Bij vroege zaai kan het voorkomen dat de planten door een koud voorjaar gaan schieten (Buishand, 1981), volgens de klimaatscenario's stijgt de temperatuur in het voorjaar waardoor dit risico mogelijk daalt. Uit de teelthandleiding (Buishand, 1981) komt naar voren dat de effecten van vochttekort kunnen leiden tot kwaliteitsproblemen zoals diepe ringen (flessehalzen), kleine worteltjes aan de peen zelf (baardigheid) en groeischeuren. Het laatstgenoemde effect treedt op wanneer er na een lange droge periode regen valt of te laat wordt beregend, waardoor het gewas te veel vocht opneemt en de worteldruk hierdoor zodanig toeneemt dat er groeischeuren ontstaan (Buishand, 1981; Sukkel et al., 2004) (D. Van Balen, persoonlijke communicatie, 12 november 2020). Volgens D. Van Balen (persoonlijke communicatie, 8 maart 2020) kunnen hogere temperaturen in het najaar gunstig zijn doordat deze een snellere afrijping bevorderen en daardoor beschadigingen aan de peen voorkomen, maar dit kan anderzijds tot hogere kosten leiden doordat er meer energie nodig is om producttemperatuur in de bewaring voldoende snel naar beneden te krijgen. Uit onderzoek van Wurr e.a. (Wurr et al., 1998) in het Verenigd-Koninkrijk komt naar voren dat de toename van de CO2-concentratie in de atmosfeer kan bijdragen aan hogere fysieke opbrengsten van peen.

\subsubsection{Effecten klimaatverandering op ziekten en plagen}

Volgens Groenkennisnet (2016) de wortelvlieg wortelvlieg (Psila rosae) is in de Nederlandse peenteelt een van de belangrijkste plagen. Vooral in een jong gewas kan de vlieg voor behoorlijke schade zorgen doordat de maden van de vlieg gangen vreten in de wortel waardoor de wortel beschadigd en in kwaliteit achteruitgaat. Na de oogst kunnen de maden achterblijven in de grond en vervolgens poppen om in het voorjaar een nieuwe generatie vliegen te vormen (Groenkennisnet, 2016). Ook de wortelmineervlieg (Napomyza carotae) kan volgens Buishand (Buishand, 1981) grote schade aanrichten doordat larven mineren (gangen vreten) van de voet van de bladstengel tot halverwege of 
hoog in de steel, daarbij kunnen de larven gangen maken in de kop van de peen. Volgens D. Van Balen (persoonlijke communicatie, 12 november 2020) zijn warmere winters gunstiger voor vliegen om te overwinteren waardoor de populatie in het voorjaar in de toekomst mogelijk toeneemt. Het precieze effect op de teelt is onduidelijk, hogere temperaturen in het voorjaar kunnen de cyclus van de insecten mogelijk versnellen waardoor telers mogelijk de eerste vlucht kwijt zijn (uitgaande van eenzelfde zaaidatum als die men nu hanteert). Uit de studie van Coakley, Scherm, \& Chakraborty (1999) komt naar voren dat de toename van de CO2-concentratie ervoor zorgt dat er bij peen meer koolstof wordt opgeslagen in de wortel wat er mogelijk voor dat het risico op bodemziektes afneemt. Hier staat tegenover dat bladziektes worden gestimuleerd bij hogere temperaturen en natte omstandigheden waardoor de opbrengsten mogelijkerwijs afnemen (D. Van Balen, persoonlijke communicatie, 12 november 2020). Voorbeelden zijn loofverbruining (Alternaria dauci) (waardoor het peenloof in korte tijd kan afsterven), zwarte vlekken (Alternaria radicina en Mycocentrospora acerina) en Cavity spot (veroorzaakt door Pythium violae) (Buishand, 1981; Sukkel et al., 2004), welke door toenemende natte omstandigheden tijdens de oogst voor meer problemen kunnen gaan zorgen (D. Van Balen, persoonlijke communicatie, 12 november 2020). Bij warme en droge periodes in het groeiseizoen worden de omstandigheden mogelijk gunstiger voor ziektes, zoals echte meeldauw en schurft (D. Van Balen, persoonlijke communicatie, 12 november 2020). De schimmels van de echte meeldauw voeden zich met plantencellen waardoor het blad verkleurd (Groen Kennisnet, 2019), bij schurft ontstaat er op de wortel een roodbruine oppervlakkige aanslag ontstaat die tot diep in de wortel kan gaan (Buishand, 1981). Volgens D. Van Balen (persoonlijke communicatie, 12 november 2020) kan bij een droge zomer de peenruggen op klei- en zavelgrond scheuren waardoor de wollige slawortelluis makkelijker bij de peenwortels kan komen waardoor de groei stagneert. De hogere temperaturen in combinatie met de hogere intensiteit neerslag in de zomer en het najaar kan het risico op violet wortelrot vergroten. De kans dat deze schimmel voor problemen zorgt hangt samen met een laag zuurstofgehalte in het bewortelde deel van de bodem en verdichte lagen (Buishand, 1981). Volgens D. Van Balen (persoonlijke communicatie, 12 november 2020) kan een hogere temperatuur in een najaar ervoor zorgen dat de temperatuur in wondhelingsperiode te lang hoog blijft, waardoor er meer kans is op infecties door bacteriën en schimmels. Daarbij kunnen de kosten van bewaring stijgen doordat er meer energie nodig is om de producttemperatuur in de bewaring voldoende snel naar beneden te krijgen.

\section{$2.4 \quad$ Wintertarwe}

\subsubsection{Effecten klimaatverandering op kwaliteit en fysieke opbrengsten}

Uit de teelthandleiding van wintertarwe (Darwinkel, 1997) blijkt dat de hoofdgrondbewerking en zaaibedbereiding afhankelijk zijn van de bodem- en weersomstandigheden. Wintertarwe kan vanaf half september tot begin februari worden gezaaid. Om de gewasontwikkeling te bevorderen dient de wintertarwe voor de vorst te uit te stoelen waardoor de aanlegging van de eerste zijspruiten in de winter of in het vroege voorjaar plaatsvindt. Tijdens de winter kan het gewas na een periode van gematigde temperaturen opgevolgd met een periode van strenge vorst doodvriezen of kan er ernstige uitwintering optreden (afsterven van planten, over het algemeen zijn met name jonge planten hier gevoelig voor) doordat het gewas onvoldoende tijd heeft om af te harden. In de toekomst nemen de temperaturen onder de klimaatscenario's de winter toe en liggen de extreemste minima hoger. Volgens Darwinkel (Darwinkel, 1997) zijn voor de ontwikkeling en de groei van wintertarwe hoge temperaturen ongunstig ( $30^{\circ} \mathrm{C}$ ). Deze hoge temperaturen gaan vaak samen met een vochttekort. Een vochttekort in het voorjaar leidt tot een lagere stikstofopname waardoor het gewas kan achterblijven in de groei. Een vochttekort tijdens de stengelstrekking kan dit leiden tot een vermindering van het aantal aandragende halmen doordat spruiten worden beperkt in hun groei. Droogte tijdens de korrelvulling beïnvloed de korrelzetting wat zorgt voor loze pakjes (het aantal korrels in een aar dat niet gevuld geraakt is). Tijdens de korrelvulling leidt hitte tot een versnelde bladafsterving, een lagere fysieke opbrengst en in extreme gevallen in kleine verschrompelde korrels. De duur van de periode korrelgroei wordt in belangrijke mate bepaald door de temperatuursom gerekend vanaf het begin van de bloei (Darwinkel, 1997). Door de toename van de temperaturen in het groeiseizoen neemt de temperatuursom sneller toe kan er mogelijk eerder worden geoogst. Door de afname van neerslag in de $\mathrm{GH}_{H^{-}}$en $\mathrm{W}_{\mathrm{H}^{-}}$-scenario's daalt mogelijk het risico op schot waarbij de 
korrels in de aar tot kieming overgaan. Met de toename van de maximale neerslag per uur en de combinatie van wind kan het risico op legering toenemen wat tot aanzienlijke opbrengstverliezen kan leiden (D. Van Balen, persoonlijke communicatie, 12 november 2020).

Uit de econometrische analyse door Powell \& Reinhard (2016) blijkt dat het risico voor wintertarwe naar verwachting toeneemt. De studie laat zien dat de periodes met het aantal hoge temperaturen toeneemt en dat het aantal periodes met lage temperaturen afneemt. De stijging van de temperaturen worden veroorzaakt door een toename van de CO2-concentratie in de atmosfeer (Klein Tank et al., 2014). Uit de studie van Manderscheid \& Weigel (2007) blijkt dat een toename van de CO2concentratie onder droogte de bodembedekking van wintertarwe stimuleert en dat de seizoensgebonden stralingsabsorptie minder afneemt. Hierdoor worden de effecten van droogte op wintertarwe gemitigeerd door een toename van CO2-concentratie. Onder omstandigheden met voldoende waterbeschikbaarheid zijn de positieve effecten van een toename van CO2-concentratie beperkter waar te nemen.

\subsubsection{Effecten klimaatverandering op ziekten en plagen}

De teelthandleiding (Darwinkel, 1997) geeft aan dat bij deelt van wintertarwe de bladluizen grote graanluis (Sitobion avenae), grootgrasluis (Metopolophium dirrhodum) en vogelkersluis (Rhopalosiphum padi) risico voor het gewas vormen. De genoemde bladluizen scheiden honingdauw uit waarop zwartschimmels zich kunnen ontwikkelen. Door het zuigen van de bladluizen kunnen bladeren gele plekken vertonen en versneld afsterven. Dit zorgt er vervolgens voor dat de fotosynthese en hierdoor de productie afneemt. Bladluizen kunnen daarnaast ook een rol spelen in virusoverdracht, zoals bij het gerstevergelingsvirus (Darwinkel, 1997). Onder de klimaatscenario's neemt naar verwachting de temperatuur in de winters toe, mogelijk worden hierdoor de omstandigheden waarin bladluizen kunnen overwinteren gunstiger (Dean, 1974). Naar verwachting zal door een toename van warme en natte omstandigheden het risico van schimmels voor wintertarwe toenemen, dit kan gelden voor verschillende ziektes, zoals: bladseptoria (Septoria tritici) en verschillende Fusarium-soorten (Darwinkel, 1997; Juroszek \& von Tiedemann, 2013; Parikka, Hakala, \& Tiilikkala, 2012). Volgens D. Van Balen (persoonlijke communicatie, 12 november 2020) kunnen onder droge omstandigheden in de zomer ziektes als meeldauw vaker voorkomen. De risico's op ziektes kunnen ook toenemen wanneer gewasresten slecht verteren doordat de grond niet bewerkt kan worden door te natte omstandigheden waardoor er voetziektes op gewasresten blijven zitten en in de volgende teelt het gewas infecteren.

\subsection{Suikerbiet}

\subsubsection{Effecten klimaatverandering op kwaliteit en fysieke opbrengsten}

Uit de teelthandleiding van suikerbieten (Westerdijk, Zwanepol, Heijbroek, \& Houtman, 1994) komt naar voren dat grondbewerking van dit gewas op zware zavel- en kleigronden veelal wordt uitgevoerd voor de winter. Op lichte gronden varieert deze vaak tussen het late najaar en het vroege voorjaar. Op zand-, löss en dalgronden is het mogelijk om dit in het voorjaar uit te voeren. Het is van belang dat grondbewerking niet onder te natte omstandigheden gebeurd. Onder de klimaatscenario's neemt de hoeveelheid neerslag in het voor- en najaar toe waardoor het aantal gunstige momenten om de grondbewerking uit te voeren dalen wat resulteert in een verhoogde kans op verslemping en verdichting. Voor een optimale ontwikkeling van het gewas stellen Westerdijk e.a. (Westerdijk et al., 1994) geeft aan dat voor een goede gewasontwikkeling het van belang is dat het perceel vrij is van verdichte lagen zijn. Voor de kieming zijn minimale temperaturen van $3-5^{\circ} \mathrm{C}$ vereist, wanneer de bodem dicht bij deze minimumtemperatuur komt resulteert dit in een trage opkomst. Door vroeger te zaaien wordt het groeiseizoen verlengd en de opbrengstpotentie hoger. Door nachtvorst kan grote schade worden toegebracht aan de jonge plantjes. Koude periodes al dan niet gepaard met natte omstandigheden, verhogen het risico op schieters, waarbij de bieten van de vegetatieve fase overgaan in de generatieve fase (vernalisatie). De bieten met schieters vormen bloeistengels welke nadelig zijn voor de kwaliteit (lager suikergehalte bepalend bij hoogte uitbetaling) en fysieke opbrengsten (Westerdijk et al., 1994). Onder de klimaatscenario's hogere temperaturen in het voorjaar zullen de 
risico's door nachtvorst en koude periodes mogelijk afnemen. In deze periode neemt de neerslaghoeveelheid onder de klimaatscenario's toe waardoor het zaad mogelijk eerder gaat rotten of dat door de kou de bieten gaan schieten (Westerdijk et al., 1994). De hogere temperaturen in het voorjaar kunnen daarnaast een positief effect hebben op de gewasontwikkeling, zoals een vlotte kieming en bladvorming (tot circa $25^{\circ} \mathrm{C}$ ) (Westerdijk et al., 1994). De teelthandleiding door het IRS (2020) geeft aan dat bij zeer hoge temperaturen (etmaalgemiddelde $>20^{\circ} \mathrm{C}$ ) de efficiëntie van de productie van droge stof afneemt. Onder de klimaatscenario's stijgen de temperaturen waardoor zeer hoge etmaalgemiddelde vaker gaan voorkomen waardoor de productie van droge stof vaker negatief wordt beïnvloed. De risico's op droogte zijn het grootst in de $\mathrm{GH}_{\mathrm{H}}$ - en WH-scenario's. Voor het optimale suikergehalte is het van belang dat de suikerbieten niet te vroeg, maar ook niet te laat, worden geoogst. Bij een te vroege oogst wordt een toename van het suikergehalte gemist en bij een late oogst neemt de kans op vorst toe waardoor het suikergehalte in de biet kan afnemen (IRS, 2020). In de klimaatscenario's neemt naar verwachting het aantal periodes met vorst af, maar neemt de frequentie van natte omstandigheden toe.

\subsubsection{Effecten klimaatverandering op ziekten en plagen}

Uit de teelthandleiding (IRS, 2020) blijkt dat bij de teelt van suikerbieten veel schimmels een rol kunnen spelen. De schimmel Rhizoctonia Solani is een veroorzaker van wortelbrand (kiemplantwegval) en wortelrot. Door een zware aantasting kan een heel perceel geïnfecteerd raken waardoor er forse opbrengstderving op kan treden. Rhizoctonia Solani wordt bevordert door verschillende waardplanten zoals waspeen en onkruiden. Daarnaast dragen warme en vochtige omstandigheden eraan bij dat de schimmel de wortel kan binnendringen. Met name zandgronden zijn gevoelig voor deze bodemschimmel, omdat deze relatief snel opwarmen. Bij hoge temperaturen en vochtige omstandigheden kan een schimmel als Aphanomyces de bieten aantasten. Suikerbieten zijn gevoelig voor verschillende bladschimmels zoals Cercospora (optimale temperatuur $23-27^{\circ} \mathrm{C}$ ), Ramularia (alleen bij koele omstandigheden, $\left.16-18^{\circ} \mathrm{C}\right)$, roest $\left(15-22^{\circ} \mathrm{C}\right)$, echte meeldauw $\left(15-30^{\circ} \mathrm{C}\right)$, Stemphylium (matige temperaturen, $16-18^{\circ} \mathrm{C}$, hoge luchtvochtigheid). Het virus Rhizomanie kan door de overbrengende schimmel Polymyxa betae de bieten aantasten waardoor deze achterblijven in groei door het verkleuren van het blad en het afsterven van de haarwortels. Aantasting kan resulteren in een laag suikergehalte, gewichtsverlies, afname van winbaarheid, stijging van tarra percentage en moeilijkere verwerkbaarheid. Het virus verspreidt zich het best onder natte omstandigheden, een slechte bodemstructuur en afwatering. De bodemschimmel Verticillium kan via de bodem de suikerbiet besmetten waarop de vaatbundels verstopt kunnen raken en hierop het blad vergeeld en uiteindelijk kan afsterven. Stimulerende factoren zijn zijn zuurstofarme omstandigheden (bijvoorbeeld extreme neerslag) en een slechte bodemstructuur. De schimmel wordt beïnvloed door verschillende aaltjes: bietencysteaaltjes, wortellesieaaltjes en wortelknobbelaaltjes. Bodemschimmels Violetwortelrot en Aphanomyces kunnen door een slechte bodemstructuur en natte omstandigheden de suikerbieten aantasten (IRS, 2020). Door klimaatverandering kunnen schimmels - door de toename van warme, natte periodes en droge periodes - een groter risico vormen voor de teelt van suikerbieten.

Volgens IRS (IRS, 2020) vormen aaltjes een risico voor de kwaliteit en fysieke opbrengsten van suikerbieten. Bietencysteaaltjes (wit bietencysteaaltje (Heterodera schachtii) en geel bietencysteaaltje (Heterodera betae)) kunnen bij jaren met voldoende vochtige omstandigheden en een gunstige bodemtemperatuur voor grote schade zorgen. Het aantal generaties dat per seizoen kan worden gevormd is afhankelijk van de temperatuursom en de weersomstandigheden. Doorgaans vormen deze aaltjes drie tot vier generaties per jaar (IRS, 2020). Uit de studie door Vandenbossche, Niere, \& Vidal (2015) komt naar voren dat door de stijging van de temperaturen beide aaltjes soorten voor nog meer schade kunnen zorgen. Wortelknobbelaaltjes worden in het voorjaar actief wanneer de temperaturen gunstig zijn bij voldoende bodemvocht (IRS, 2020). Het nattere voorjaar, de drogere zomers en de hogere temperaturen zullen mogelijk de ene aaltjes meer stimuleren dan de andere. Net als in de hierboven beschreven gewassen hebben kunnen verschillende soorten insecten schade veroorzaken in bieten. Insecten kunnen zich door de hogere temperaturen waarschijnlijk eerder en vaker per seizoen voortplanten. 


\section{Adaptatiemaatregelen}

Hoofdstuk 1 heeft gepresenteerd dat de beschikbaarheid van water (teveel of te weinig) en de kwaliteit ervan (verzilting) beïnvloed gaan worden door klimaatverandering. Hoofdstuk 2 heeft aangegeven wat dat voor de specifieke akkerbouwgewassen betekend, en waar adaptatie dus nodig is. Om daarop voor te bereiden, kunnen verschillende maatregelen genomen worden om de grilligheid van de beschikbaarheid en kwaliteit van water te dempen. In Verstand et al. (2020) zijn maatregelen gelinkt aan de klimaattrend en bedreigingen die genoemd zijn in de NAS bollenschema's. Echter, voor veel van deze maatregelen bestaan nog onzekerheden en is niet goed bekend hoe goed ze werken en of ze meer opleveren dan ze kosten. Tevens moet er ervaring opgedaan worden in de praktijk hoe een maatregel precies toegepast kan worden. Vanuit de boer gaat het immers om hoe goed de maatregel werkt, maar ook over hoe goed die toepasbaar op het bedrijf is. Dat is waar deze PPS klimaatadaptatie in de open teelten aan werkt.

Dat is als volgt gedaan:

Door betrokken experts is in het begin van het project een longlist maatregelen opgesteld waarvoor het nodig is dat er ervaring wordt opgedaan in het veld betreft effectiviteit en toepasbaarheid. Vanuit die longlist zijn maatregelen geselecteerd die in de praktijk toegepast en gevolgd gaan worden. Op basis van twee jaar experimenten zijn factsheets ontwikkeld die overzicht bieden en daarmee helpen om de keuze te maken welke maatregelen voor welke situatie, grondsoort en gewas een goede optie zijn/gaat worden.

\section{$3.1 \quad$ Longlist}

De longlist dient als startpunt en is opgesteld op basis van expertise bij partners (Agrifirm, SPNA, WUR), praktijk kennis en eerdere rapporten. De lijst gaat uit van een aantal maatregelcategorieën, waaronder een aantal specifieke maatregelen zijn gehangen. Er wordt gericht op water gerelateerde maatregelen, die destijds opgedeeld zijn in 3 categorieën: Organische stofaanvoer, opvang van regenwater en efficiënt watergebruik. Hieronder zijn de losse maatregelen die uit de inventarisatie kwamen opgesomd.

Organische stofaanvoer. Organische stof kan de waterberging in de bodem verhogen: $1 \%$ punt extra organische stof levert tussen $3 \mathrm{~mm}$ (op kleigrond) en $6 \mathrm{~mm}$ (op zand) extra waterberging per neerslag event (Wösten, Veerman, de Groot, \& Stolte, 2001). Er zijn een aantal opties:

- Maximalisatie groenbemester droge stof productie (mengsels, laat onderwerken (voorjaarsploegen)

- Gereduceerde grondbewerking vanwege verminderde afbraak organische stof (1,7\% afbraak ipv $2 \%$ )

- Extra aanvoer van organische stof:

- middels compost en/of bokashi

- Vaste mest ipv drijfmest ivm hogere aanvoer os met gelijke aanvoer fosfaat

- Aanpassen van bouwplan (meer graan en/of gewassen met hogere os aanvoer)

Opvang van regenwater. Zoals eerder beschreven gaat er in de herfst, winter en lente meer neerslag vallen dan in het verleden. In de zomer stijgt de vraag door een lager neerslag (in de $\mathrm{W}$ klimaatscenario's) en door de hogere vraag door stijgende temperaturen. Opties:

- Opvang van drainwater (gaat samen met druppelirrigatie)

- Opvang in bassin

- Opvang in zoetwaterbel (bedrijfsoverstijgend?)

- Peilgestuurde drainage (plaatselijke opslag in de bodem) 
Verbeteren van waterinfiltratie. Het verbeteren van infiltratie van water zorgt ervoor dat water langer in de bodem opgeslagen blijft, zodat planten het later weer kunnen benutten. Dit kan gerealiseerd worden door.

- Voorkomen van ingesloten laagtes:

- Egaliseren van perceel

- Bolleggen van perceel

- Gebruik van transformer(achtige) hulpstoffen

- bewerkingen om afspoeling van regenwater te voorkomen; erosiestoppers

- Ondergrondverdichting voorkomen ten bate van gewasgroei:

- Verlagen bodemdruk (rupsbanden, drukwisselsysteem, lage druk banden)

- Bovenover ploegen

- De grond berijden als deze droog is

- Gereduceerde grondbewerking voor het verhogen van de draagkracht van de bodem

- Ondergrondverdichting opheffen:

- Plaatselijk opheffen van verdichte laag (gaten boren Werkpakket 3)

- Diepwortelende (groenbemestings)gewassen

- Optimalisatie van drainage

- Tussendrainage

- Drainonderhoud

- Voorkomen van slemp:

- Zoveel mogelijk bedekt houden van de grond:

- Groenbemesters laat onderwerken

- Gereduceerde grondbewerking (opbouw van organische stof in toplaag)

- Gebruik van mulch

- Ca toestand optimaliseren

- Opheffen van slemp:

- Schoffelen of eggen

- Breedspoor - rijpadensysteem

Efficiënt watergebruik. Door goed om te gaan met de beschikbare hoeveelheden water, kan de gewasgroei ook in droge periode plaatsvinden. Daar hoort ook bij dat het water de juiste kwaliteit heeft.

- Efficiënt beregenen;

- Druppelirrigatie

- Gebruik van Beslissings ondersteunende systeem (BOS) voor het optimaliseren van het gebruik van irrigatiewater. Zo kan op het juiste moment beregend worden. 


\subsection{Maatregelen in teeltjaar 2020}

Vanuit deze longlist en het PPS projectvoorstel zijn voor het teeltjaar 2020 een aantal maatregelen uitgekozen waarmee in verschillende proefopzetten op proef en praktijkbedrijven is geëxperimenteerd. Hieronder een overzicht van de maatregelen en bijbehorende informatie van de proeven.

Tabel 5. Overzicht van de onderzochte adaptatiemaatregel, het gebied waarin de maatregel is toegepast, en de reden voor toepassing en onderzoek.

\begin{tabular}{|c|c|c|}
\hline Maatregel & Akkerbouw gebied & Reden \\
\hline $\begin{array}{l}\text { Ondergrondverdichting opheffen } \\
\text { door gaten van } 10 \mathrm{~cm} \text { doorsnee } \\
\text { te boren }\end{array}$ & Kleigrond IJsselmeerpolders & $\begin{array}{l}\text { Doorboren van een verdichte kleilaag, die waterinfiltratie vermindert } \\
\text { en het diepwortelen van gewassen (naar onder andere water) hindert. }\end{array}$ \\
\hline $\begin{array}{l}\text { Ondergrondverdichting opheffen } \\
\text { door gaten van } 2 \mathrm{~cm} \text { doorsnee te } \\
\text { boren }\end{array}$ & Kleigrond IJsselmeerpolders & $\begin{array}{l}\text { Doorboren van een verdichte kleilaag, die waterinfiltratie vermindert } \\
\text { en het diepwortelen van gewassen (naar onder andere water) hindert. }\end{array}$ \\
\hline $\begin{array}{l}\text { Poten in breedspoor rijpaden } \\
\text { systeem }\end{array}$ & $\begin{array}{l}\text { Kleigrond, Noordelijk } \\
\text { kleigebied }\end{array}$ & Voorkomen van ondergrondverdichting \\
\hline Groenbemesters & $\begin{array}{l}\text { Kleigrond Noordelijk } \\
\text { kleigebied }\end{array}$ & Organische stofaanvoer en verbeteren bodemstructuur \\
\hline Toepassen Transformer & $\begin{array}{l}\text { Kleigrond Noordelijk } \\
\text { kleigebied }\end{array}$ & $\begin{array}{l}\text { Testen of een droge bodem met Transformer beter water vast kan } \\
\text { houden }\end{array}$ \\
\hline Drempels in aardappelruggen & $\begin{array}{l}\text { Kleigrond Noordelijk } \\
\text { kleigebied }\end{array}$ & Erosiestopper en vasthouden van water zodat het kan infiltreren \\
\hline $\begin{array}{l}\text { Zuinig en effectief watergebruik } \\
\text { in beregening van } \\
\text { zetmeelaardappelen }\end{array}$ & Dalgrond Veenkolonien & $\begin{array}{l}\text { Zoeken naar optimale moment, juiste waterkwaliteit en meest } \\
\text { efficiënte manier van beregenen. }\end{array}$ \\
\hline
\end{tabular}

\subsection{Maatregelen in teeltjaar 2021}

In 2021 is besloten met de stuurgroep van de PPS om door te gaan met dezelfde maatregelen die ook in 2020 gevolgd zijn. Op die manier worden de ervaringen uitgebreider en de uitkomsten betrouwbaarder.

Op de noordelijke zeeklei is de toepassing met de woeltand toegevoegd, als maatregel om de infiltratie te verbeteren tussen de aardappelruggen.

De volgende video's geven een goeie impressie van de maatregelen. -maatregelen in het noordelijk kleigebied: https://www.youtube.com/watch?v=tPHhdaaw9Pk. - gaten boren om ondergrondverdichting op te heffen: https://www.youtube.com/watch?v=kcsb6ahitGg

- zuinig en effectief beregenen: https://www.youtube.com/watch?v=ZO7WF-cAPa8

\subsection{Factsheet voor adaptatiemaatregelen}

Voor de maatregelen die zowel in 2020 als in 2021 in de expirimenten aanwezig waren, zijn factsheets opgesteld (D. Verstand, 2021). Hieronder worden deze gepresenteerd. 


\section{Maatregel | Handleiding}

Introductie I Elke maatregel is in een eenduidig factsheet-format ingevuld en beoordeeld aan de hand van een aantal verschillende criteria. Hier wordt kort omschreven wat deze maatregel inhoudt en in wat voor situatie het experiment is uitgevoerd.

\section{Waarom deze maatregel?}

- Op deze plek wordt opgesomd waarom deze maatregel geïmplementeerd kan worden in het kader van klimaatadaptatie.

\section{Klimaattrend en effectiviteit}

Hier wordt kwalitatief aangegeven, op basis van het experiment en expert inschattingen, in hoeverre deze maatregel helpt met de vier klimaattrends om te gaan. Een plus betekent dat de maatregel helpt om met deze specifieke klimaattrend om te gaan. Een vraagteken betekent dat het effect onbekend is.

\section{Schaalniveau}

Hier wordt het schaalniveau waarop de maatregel toegepast wordt aangegeven.

\begin{tabular}{l|l|l} 
Droger & $-0+++$ & Plant \\
Warmer & $-0+++$ & Perceel \\
Natter & $-0+++$ & Bedrijf \\
Zeespiegel/verzilting & $-0+++$ &
\end{tabular}

\section{Type maatregel}

\section{Grondsoort}

Hier wordt aangegeven wat voor maatregel het is. Incidenteel betekent dat de maatregel wordt toegepast in het geval van het optreden van een extreem event. Preventieve maatregelen worden voor de zekerheid genomen om schade te voorkomen. Structureel betekent standaard opname in de bedrijfsvoering.

\section{Incidenteel}

Preventief

Structureel

Hier wordt aangegeven op welke grondsoorten de maatregel goed toepasbaar is.

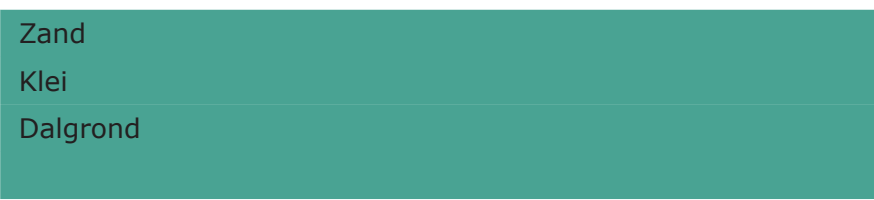

\section{Vereiste kennis}

$\mathrm{Er}$ is ingeschat hoe groot de vereiste kennis van de maatregel moet zijn voor implementatie.

\section{Eenmalige kosten per bedrij}

Hier worden de eenmalige investeringskosten per bedrijf ingeschat, aan de hand van de onderstaande bedragen.

\section{Jaarlijkse kosten per hectare}

Hier worden de jaarlijkse kosten per hectare ingeschat, aan de hand van de onderstaande bedragen.

\begin{tabular}{|c|c|}
\hline Laag & Laag $<€ 2000$ \\
\hline Midden & Midden $<€ 2000 € 4000$ \\
\hline Hoog & Hoog $<€ 4000$ \\
\hline Positieve neveneffecten & Negatieve neveneffecten/nadelen \\
\hline $\begin{array}{l}\text { Hier zijn positieve neveneffecten } \\
\text { als gevolg van de maatregel } \\
\text { benoemd. Denk aan onder andere } \\
\text { waterkwaliteit, opbrengst, arbeid, } \\
\text { biodiversiteit of klimaatmitigatie. }\end{array}$ & $\begin{array}{l}\text { Hier zijn negatieve neveneffecten als gevolg } \\
\text { van de maatregel benoemd. Denk aan } \\
\text { onder andere waterkwaliteit, opbrengst, } \\
\text { arbeid, biodiversiteit of klimaatmitigatie. }\end{array}$ \\
\hline
\end{tabular}

\section{Laag $<€ 200$ \\ Midden $<€ 200 € 500$ \\ Hoog $<€ 500$}

\section{Gewastoepassing}

Hier wordt aangegeven in welke gewassen de maatregel goed toepasbaar is.

\section{Aandachtspunten bij uitvoering}

- Hier worden aandachtspunten of afwegingen bij implementatie van de maatregel benoemd.

\section{Bronnenlijst}

Nuttige links of referenties zijn hier opgenomen.

\section{Uien}

Ardappels

Bieten

Peen

Granen

\section{Meer informatie | Daan Verstand}

Projectcoördinator Wageningen University \& Research

T| 0320-293460 | daan.verstand@wur.nl

Vormgeving | Caroline Verhoeven

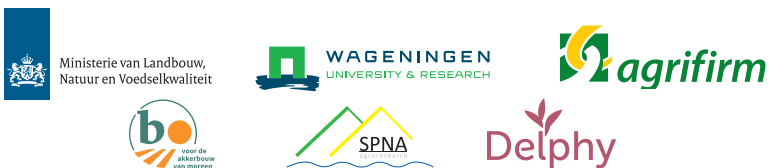



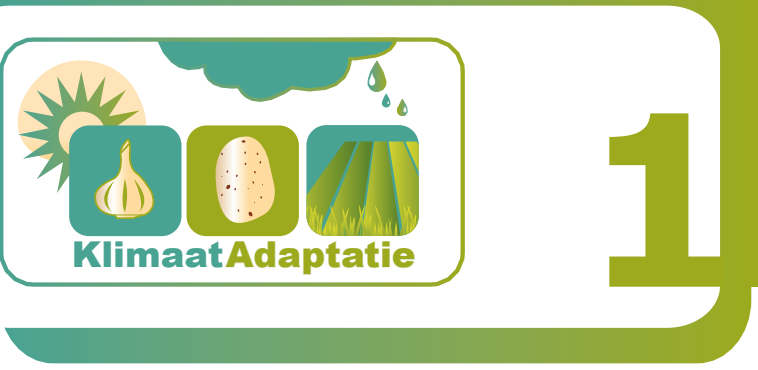

\section{Duurzaam opheffen van ondergrondverdichting}

Introductie | Wanneer de bodem onder bewerkingsdiepte is verdicht spreken we van ondergrondverdichting. Dat kan ontstaan bij het ploegen maar ook door een te hoge belasting van de bodem tijdens oogstwerkzaamheden onder natte omstandigheden. Ondergrondverdichting belemmert wortelgroei en watertransport (zowel infiltratie als capillaire opstijging) in de bodem. Het is van belang om maatregelen te treffen die op de lange termijn de ondergrondverdichting kunnen opheffen maar er ook voor zorgen dat de bodem vervolgens zo min mogelijk verstoord wordt. Om het duurzaam op te heffen, wordt er onderzoek gedaan naar het boren van gaten door de verdichte lagen heen.

\section{Waarom deze maatregel?}

Het boren van gaten kan op korte termijn (in tegenstelling tot stimuleren van bodemleven) perspectief geven aan akkerbouwers die te maken hebben met ondergrondverdichting. Echter, na het mechanisch opheffen van bodemverdichting is het belangrijk om de ondergrond te stabiliseren. Beworteling door gewassen kan hierin een belangrijke rol spelen. Met het boren van gaten in combinatie met diepwortelende groenbemester is dit mogelijk. Plantenwortels kunnen gebruik maken van de gangen door de verdichte laag en de ondergrond bezetten met wortels.

\begin{tabular}{|c|c|c|c|c|}
\hline \multicolumn{2}{|c|}{ Klimaattrend en effectiviteit } & \multirow{2}{*}{$\begin{array}{l}\text { Schaalniveau } \\
\text { Plant }\end{array}$} & \multirow{2}{*}{$\begin{array}{l}\text { Type } \\
\text { Incidenteel }\end{array}$} & \multirow{2}{*}{$\begin{array}{l}\text { Grondsoort } \\
\text { Zand }\end{array}$} \\
\hline Droger & $-0+++$ & & & \\
\hline Warmer & $-0+++$ & Perceel & Preventief & Klei \\
\hline Natter & $-0+++$ & Bedrijf & Structureel & Dalgrond \\
\hline Zeespieg & ? & & & \\
\hline
\end{tabular}

\begin{tabular}{l|l|l|l|l|l|}
\hline Vereiste kennis & Eenmalige kosten & Jaarlijkse kosten & Positieve neveneffecten & Negatieve neveneffecten & Gewassen \\
\hline Laag & Laag & Laag & Waterkwaliteit & Meer arbeid & Uien \\
\hline Midden & Midden & Midden & Klimaatmitigatie & Aardappels \\
\hline Hoog & Hoog & Hoog & Gewasopbrengst & Bieten \\
& & & & Peen \\
\end{tabular}

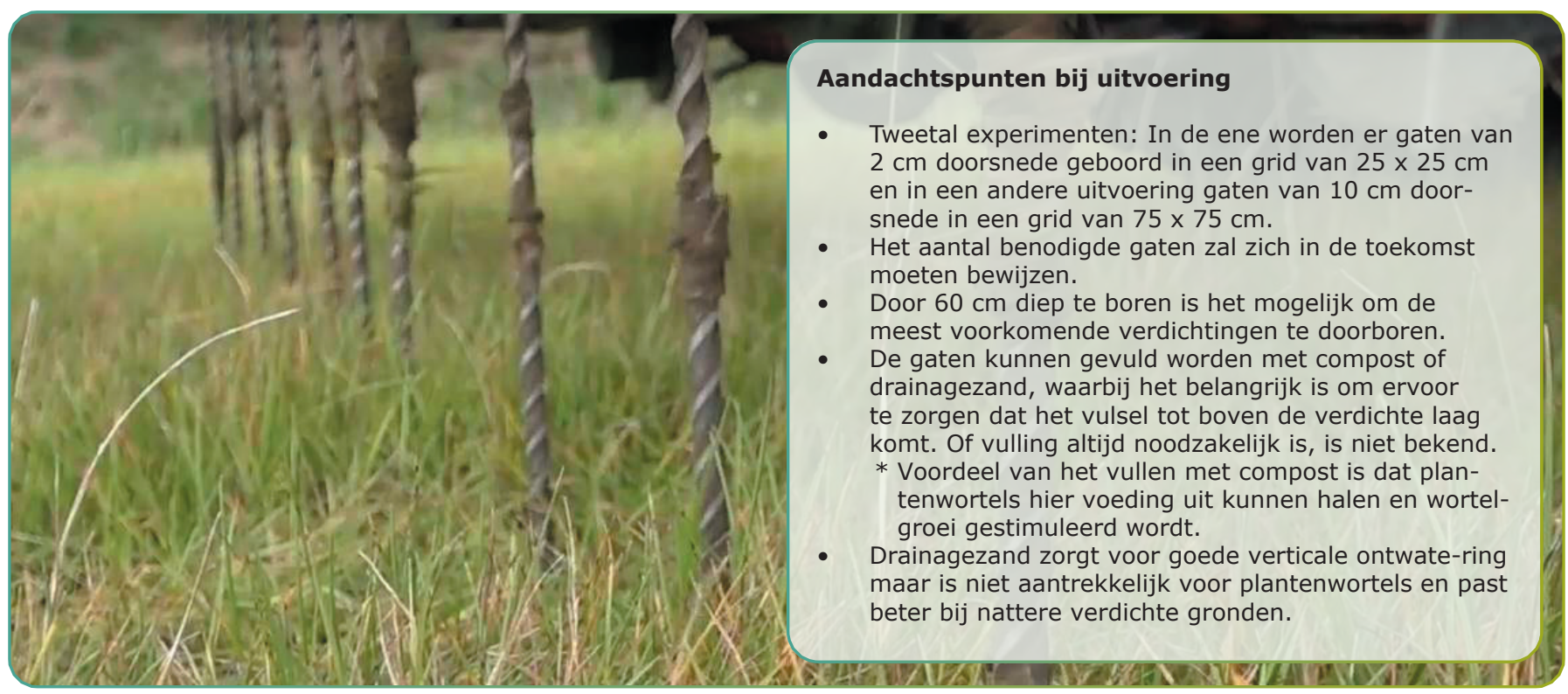




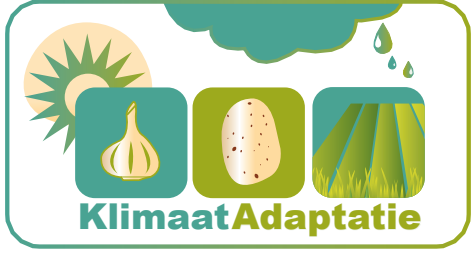

\section{Groenbemester}

Introductie | Voor deze maatregel is de groenbemester Japanse Haver vergeleken met 'braak' op een klei-perceel bij SPNA te Kollumerwaard. Eind 2019 is het perceel omgeploegd waarna vervolgens in het voorjaar van 2020 de aardappelen zijn gepoot. We hebben naar deze maatregel gekeken, omdat er steeds extremere weersinvloeden een rol spelen in het huidige klimaat in Nederland en wat groenbemesters kunnen bijdragen aan het weerbaarder maken van de akkerbouw.

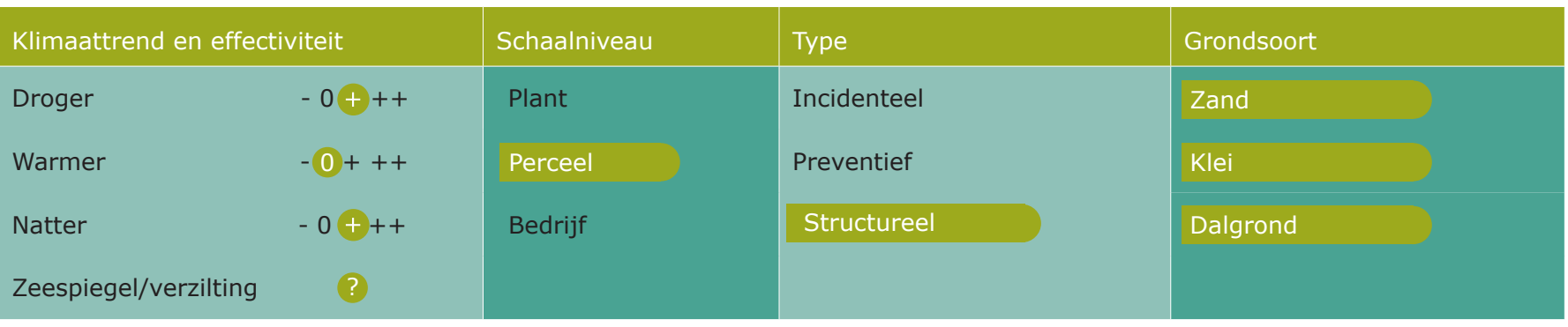

\begin{tabular}{|c|c|c|c|c|c|}
\hline Vereiste kennis & Eenmalige kosten & Jaarlijkse kosten & Positieve neveneffecten & Negatieve neveneffecten & Gewassen \\
\hline Laag & Laag & Laag & Waterkwaliteit & Extra arbeid en kosten & Uien \\
\hline Midden & Midden & Midden & $\begin{array}{l}\text { Bijdrage biodiversiteit } \\
\text { en bodemleven }\end{array}$ & & Aardappels \\
\hline \multirow[t]{3}{*}{ Hoog } & Hoog & Hoog & Erosiebescherming & & Bieten \\
\hline & & & $\begin{array}{l}\text { Onkruidgroei } \\
\text { onderdrukken }\end{array}$ & & Peen \\
\hline & & & Stikstofvanger & & Granen \\
\hline
\end{tabular}

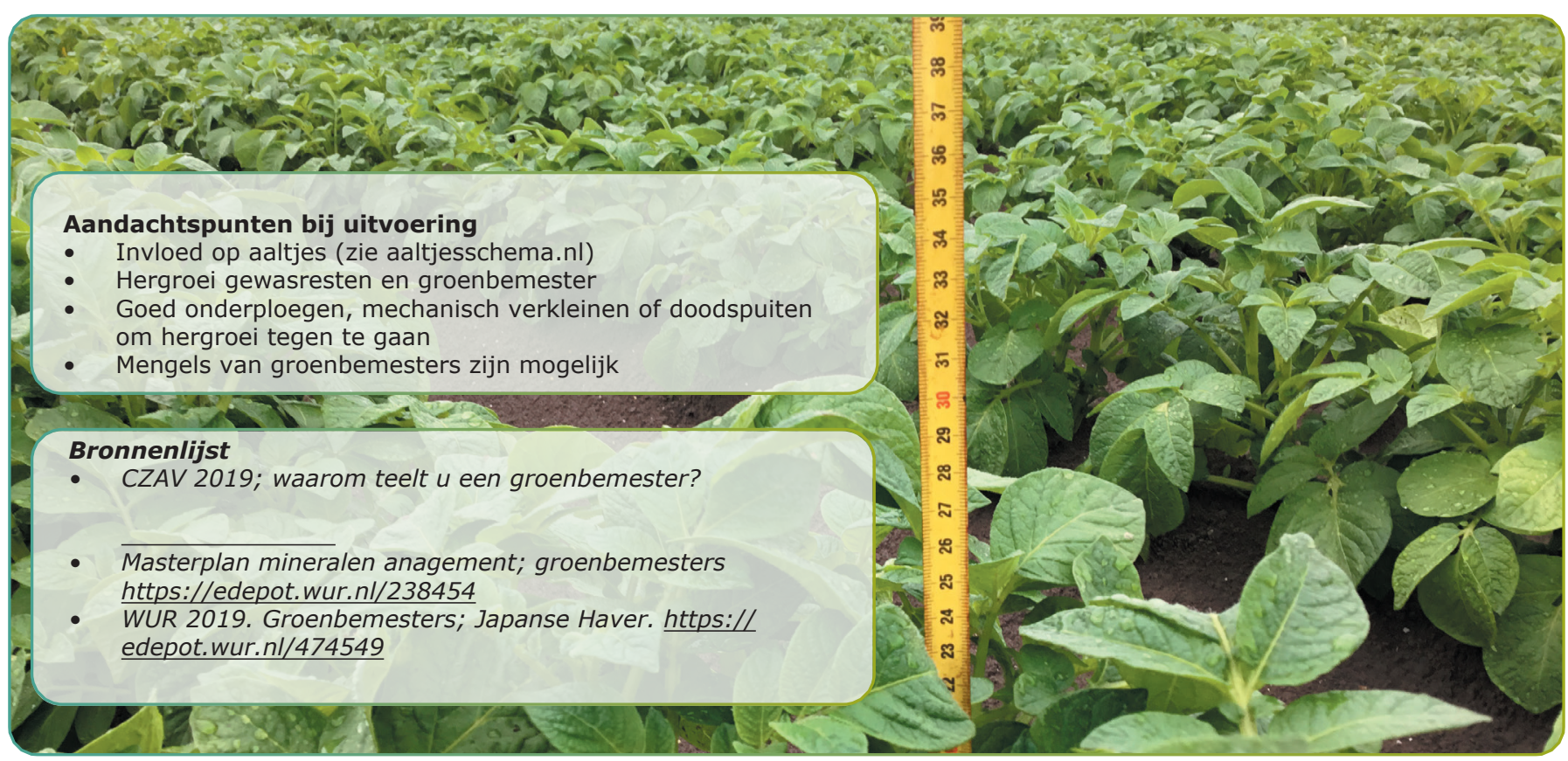

수론 Ministerie van Landbouw,
Natuur en Voedselkwaliteit

\section{Waarom deze maatregel?}

- Meer organische stof in de bodem wat leidt tot een betere waterhuishouding

- Consolideren en verbeteren bodemstructuur 


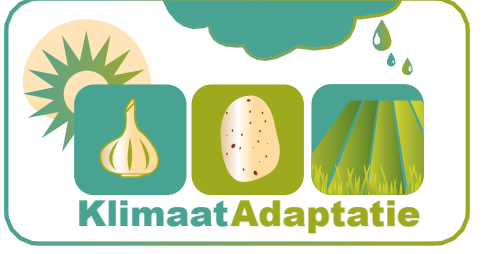

\section{Optimale vochtvoorziening in zetmeelaardappelen}

Introductie | Op steeds meer zetmeelaardappel-telende bedrijven in Noordoost-Nederland wordt beregening mogelijk, om zo de risico's op opbrengstdervingen door droogte te verlagen. Echter blijkt ook dat beregening niet altijd van meerwaarde is. Uiteraard zit er een kostenplaatje aan beregening, dus om het rendabel te maken moet de meerwaarde van beregenen de kosten ervan overtreffen. De vraag is dus hoe een teler optimaal kan beregenen. Dit betekent zo weinig mogelijk beregenen op het juiste tijdstip. Daarnaast moet het gewas gezond blijven. Vaak wordt gezien dat na beregenen het loof van de aardappelen vervroegd afsterft. Bij optimaal beregenen hoort dus ook uitzoeken wat de oorzaak hiervan is. Dit kan zijn de waterkwaliteit, maar ook de hoeveelheid water die wordt gegeven of dat het water direct aan de wortel gegeven wordt en niet over het gewas (met druppelirrigatie).

\section{Waarom deze maatregel?}

Water is in droge periodes schaars. Dat hebben we de afgelopen jaren duidelijk kunnen waarnemen. Het is dus zaak om zorgvuldig om te gaan met het beschikbare water. Daarnaast zorgt beregening voor een kostenpost. Hoe minder het nodig is des te voordeliger. Uiteraard is het van groot belang dat de opbrengst wel optimaal is. Het rendement van de zetmeelteelt is van een dusdanig niveau dat een optimale opbrengst nodig is voor een goed financieel resultaat.

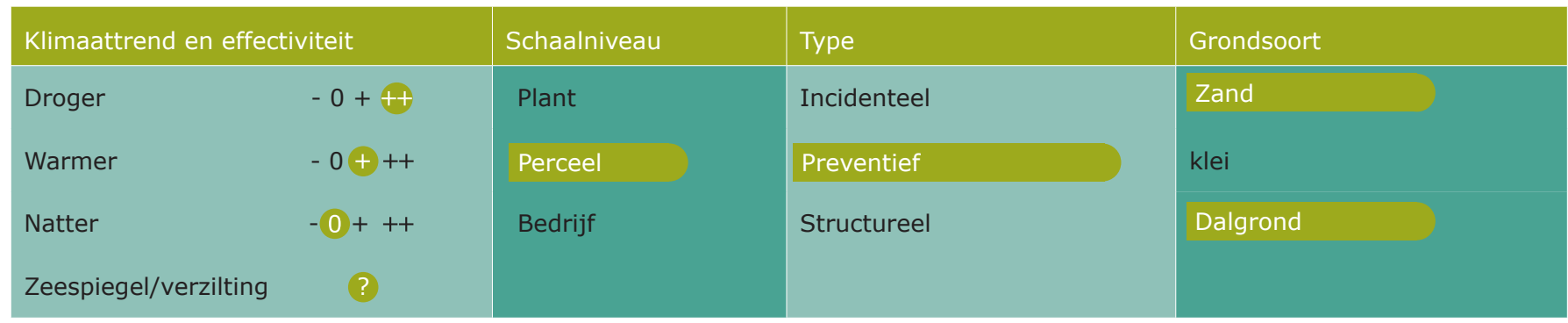

\begin{tabular}{ll|l|l|l|l|l}
\hline Vereiste kennis & Eenmalige kosten & Jaarlijkse kosten & Positieve neveneffecten & Negatieve neveneffecten & Gewassen \\
\hline Laag & Laag & Laag & Waterkwaliteit & Vervroegd afsterven & Uien \\
Midden & Midden & Midden & Gewasopbrengst & Ziekten (Phytophtora', & Aardappels \\
\hline Hoog & Hoog & Hoog & Waterbesparing & Meer arbeid & Bieten & Peen \\
& & & & Granen
\end{tabular}

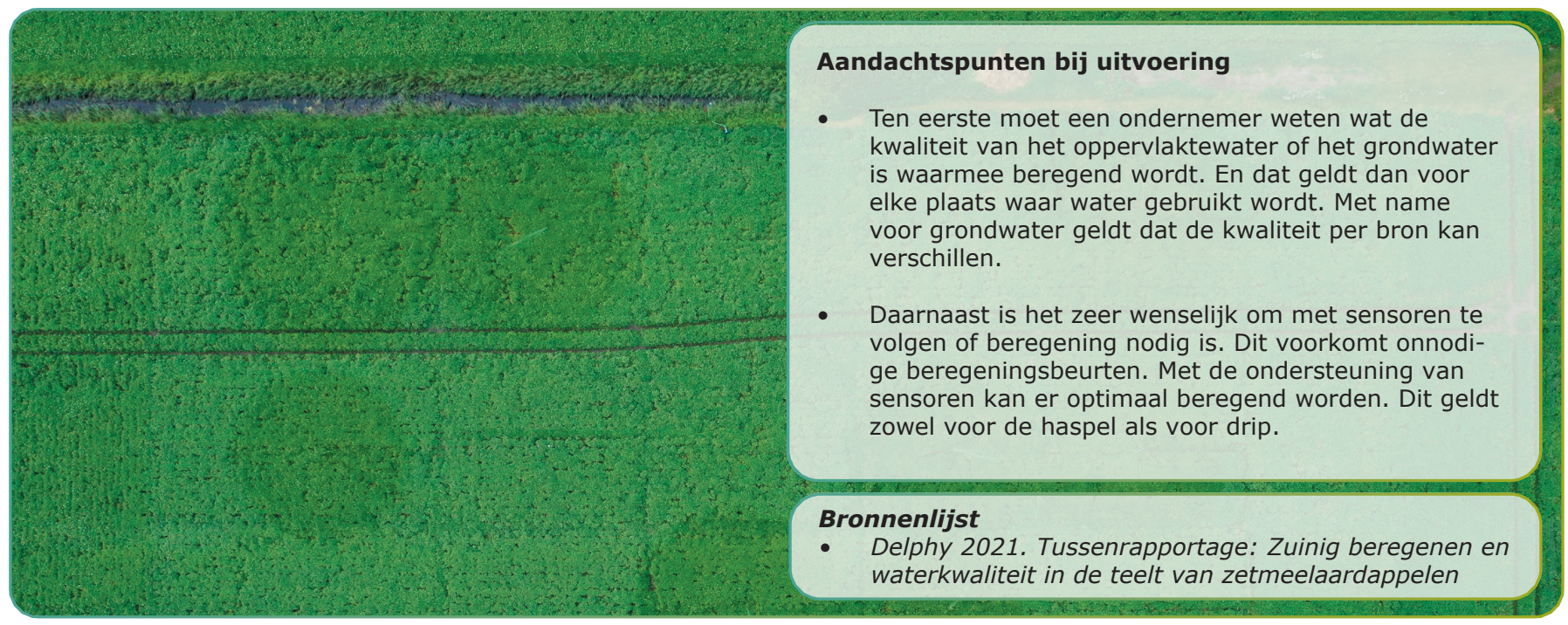






\section{Erosiestoppers}

Introductie | Voor deze maatregel zijn op een bollend perceel erosiestoppers (drempeltjes) tussen de aardappels vergeleken met de gangbare aardappelruggen zonder erosiestoppers. Deze erosiestoppers worden tijdens het aanfrezen van de aardappelruggen gerealiseerd middels drempeltjes-vormende elementen achter de frees tussen de ruggen, welke ingesteld kunnen worden op basis van de omstandigheden. Ter indicatie zijn de erosiestoppers in het experiment $7-10 \mathrm{~cm}$ hoog en zijn iedere $40-50 \mathrm{~cm}$ aangelegd. Door erosiestoppers aan te brengen op het aardappelperceel wordt de emissie beperkt en water/neerslag langer vastgehouden. Indien er een stortbui komt egaliseren de erosiestoppers en vloeit het overtollige water alsnog weg.

\section{Waarom deze maatregel?}

- Neerslag kan op het perceel infiltreren doordat het langer de tijd krijgt.

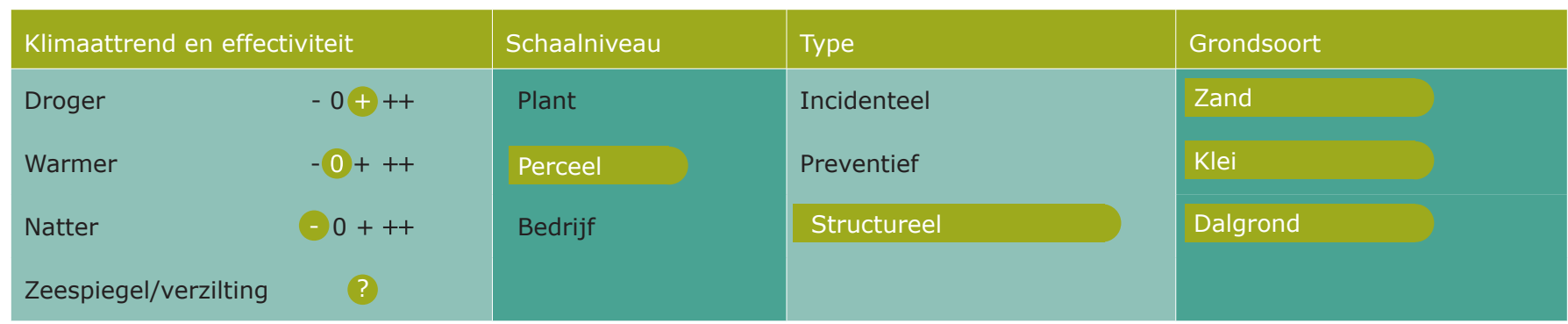

\begin{tabular}{|c|c|c|c|c|c|}
\hline Vereiste kennis & Eenmalige kosten & Jaarlijkse kosten & Positieve neveneffecten & Negatieve neveneffecten & Gewassen \\
\hline Laag & Laag & Laag & Minder afspoeling & \multirow{5}{*}{$\begin{array}{l}\text { Mogelijke water- } \\
\text { schade bij extreme } \\
\text { neerslag }\end{array}$} & Uien \\
\hline Midden & Midden & Midden & $\begin{array}{l}\text { Mogelijk hogere } \\
\text { gewasopbrengst }\end{array}$ & & Aardappels \\
\hline \multirow[t]{3}{*}{ Hoog } & Hoog & Hoog & & & Bieten \\
\hline & & & & & Peen \\
\hline & & & & & Granen \\
\hline
\end{tabular}

\section{Aandachtspunten bij uitvoering}

- Extreme neerslag moet wel kunnen wegvloeien (goede regelmaat- en hoogteverhouding erosiestoppers).

- Hoe meer hoogteverschil in het perceel, hoe kleiner de afstand tussen erosiestoppers moet zijn.

- Selectiewerkzaamheden (in de wielsporen van de selectiekar geen erosiestoppers aanbrengen).

\section{Bronnenlijst}

- Water in Balans 2020, factsheets Water vasthouden op Landbouwpercelen, en video Waterschap Limburg: https://www. youtube.com/watch?v=Jh WCtT6HmPY

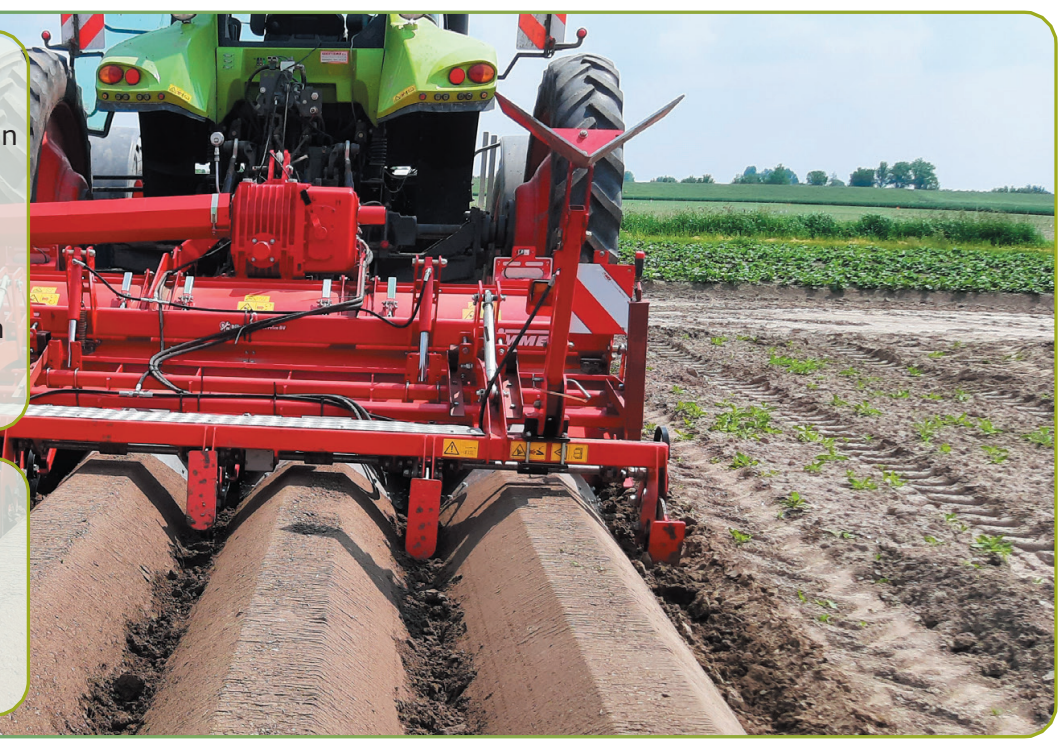




\section{Breedspoor}

Introductie I Bij het object Breedspoor wordt gebruik gemaakt van seizoens onbereden vaste rijpaden met een spoorbreedte van 3,20 m. De rijpaden zijn $20 \mathrm{~cm}$ breed waar het trekkerwiel overheen rijdt. Alleen bij de oogst van gewassen worden de bedden bereden. Hiermee worden bedden gecreëerd van 3 meter waar gewassen op een minder verdichte ondergrond kunnen groeien.

\section{Waarom deze maatregel?}

- Betere waterhuishouding bij veel neerslag.

- $\quad$ Betere capillaire werking bij droogte.

\begin{tabular}{|c|c|c|c|c|}
\hline \multicolumn{2}{|c|}{ Klimaattrend en effectiviteit } & Schaalniveau & Type & Grondsoort \\
\hline Droger & $-0+++$ & Plant & Incidenteel & Zand \\
\hline Warmer & $-0+++$ & Perceel & Preventief & Klei \\
\hline Natter & $-0+++$ & Bedrijf & Structureel & Dalgrond \\
\hline Zeespiegel/verzilting & $?$ & & & \\
\hline
\end{tabular}

\begin{tabular}{|c|c|c|c|c|c|}
\hline Vereiste kennis & Eenmalige kosten & Jaarlijkse kosten & Positieve neveneffecten & Negatieve neveneffecten & Gewassen \\
\hline Laag & Laag & Laag & \multirow{4}{*}{$\begin{array}{l}\text { Betere } \\
\text { gewasopbrengst } \\
\text { in extremere jaren }\end{array}$} & \multirow{2}{*}{$\begin{array}{l}\text { Natte rijsporen bij } \\
\text { veel regenval door } \\
\text { plaatselijke verdichting }\end{array}$} & Uien \\
\hline Midden & Midden & Midden & & & Aardappels \\
\hline Hoog & Hoog & Hoog & & \multirow[t]{2}{*}{$\begin{array}{l}\text { Breed vervoers- } \\
\text { middel over de } \\
\text { openbare weg }\end{array}$} & $\begin{array}{l}\text { Bieten } \\
\text { Peen }\end{array}$ \\
\hline & & & & & Granen \\
\hline
\end{tabular}

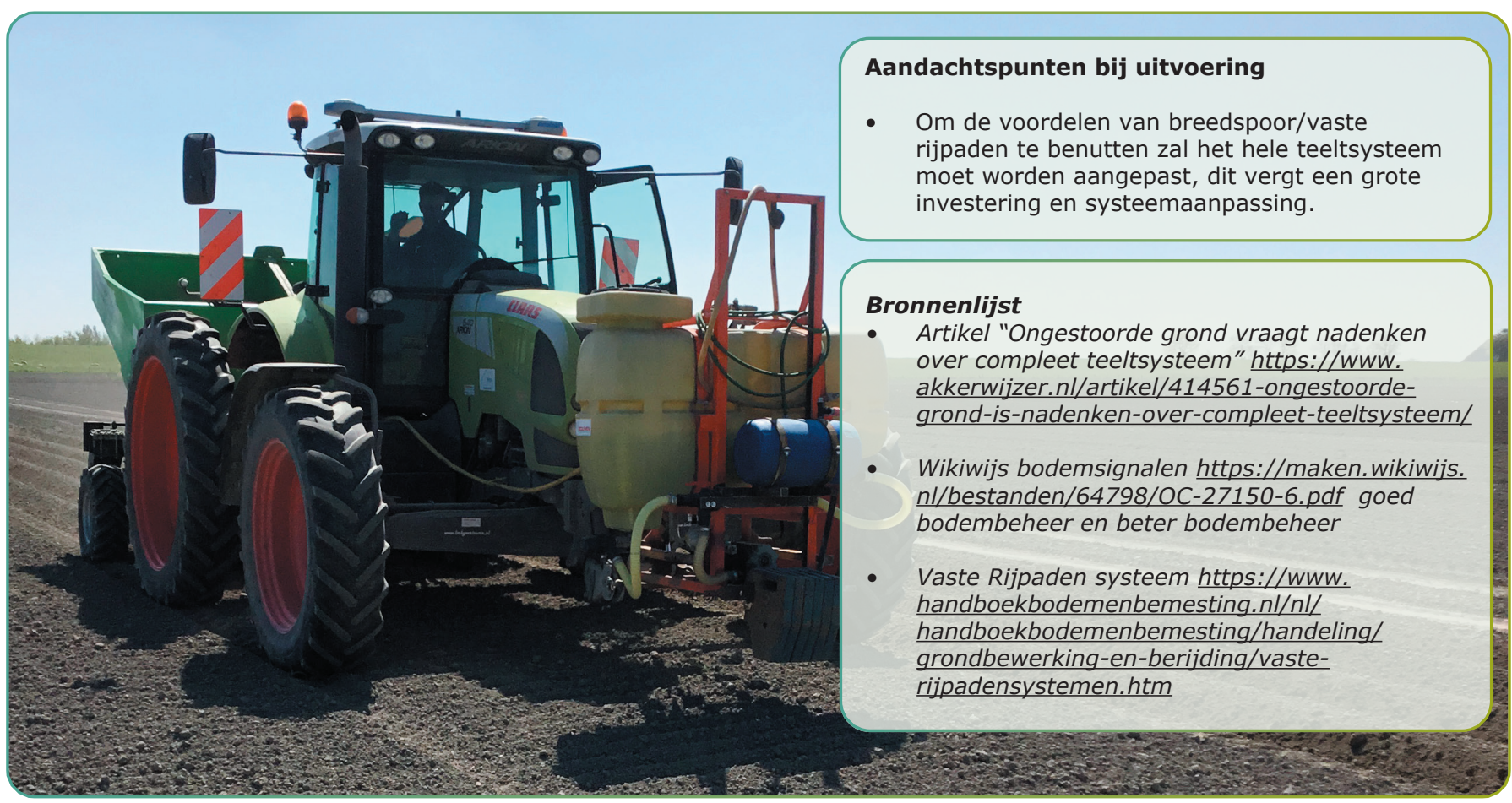




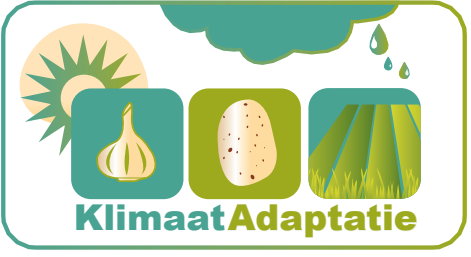

\section{Transformer}

Introductie | Transformer is een middel dat onder andere kan worden toegepast tijdens het poten van de aardappelen. Het zorgt voor een verbeterd waterabsorberend vermogen van de grond zodat de aardappelrug intact blijft bij (veel) neerslag.

\section{Waarom deze maatregel?}

- In natte perioden trekt het water beter de bodem in.

- In droge perioden beschikt het gewas beter over vocht.

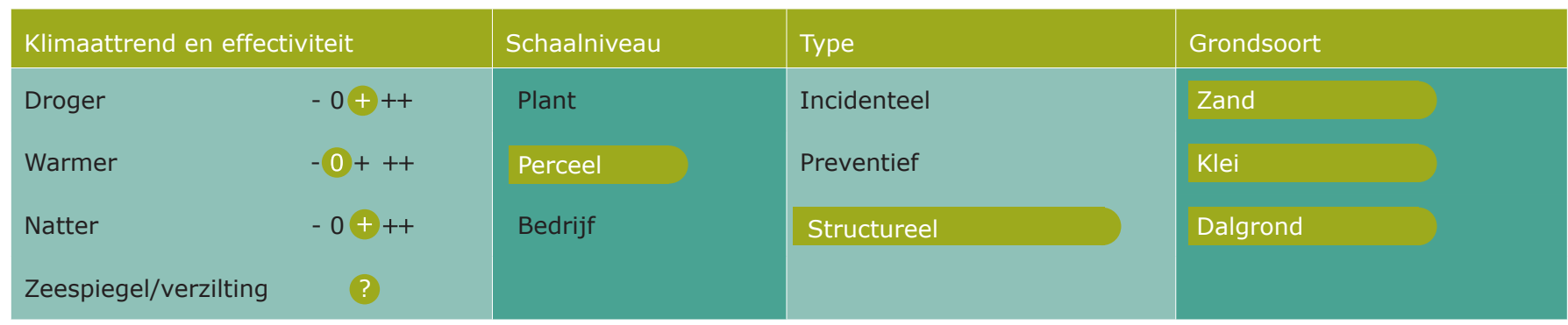

\begin{tabular}{|c|c|c|c|c|c|}
\hline Vereiste kennis & Eenmalige kosten & Jaarlijkse kosten & Positieve neveneffecten & Negatieve neveneffecten & Gewassen \\
\hline Laag & Laag & Laag & \multirow{5}{*}{$\begin{array}{l}\text { Mogelijk minder } \\
\text { afspoeling van } \\
\text { gewasbeschermings- } \\
\text { middelen en grond } \\
\text { naar oppervlaktewater }\end{array}$} & & Uien \\
\hline Midden & Midden & Midden & & & Aardappels \\
\hline \multirow[t]{3}{*}{ Hoog } & Hoog & Hoog & & & Bieten \\
\hline & & & & & Peen \\
\hline & & & & & Granen \\
\hline
\end{tabular}

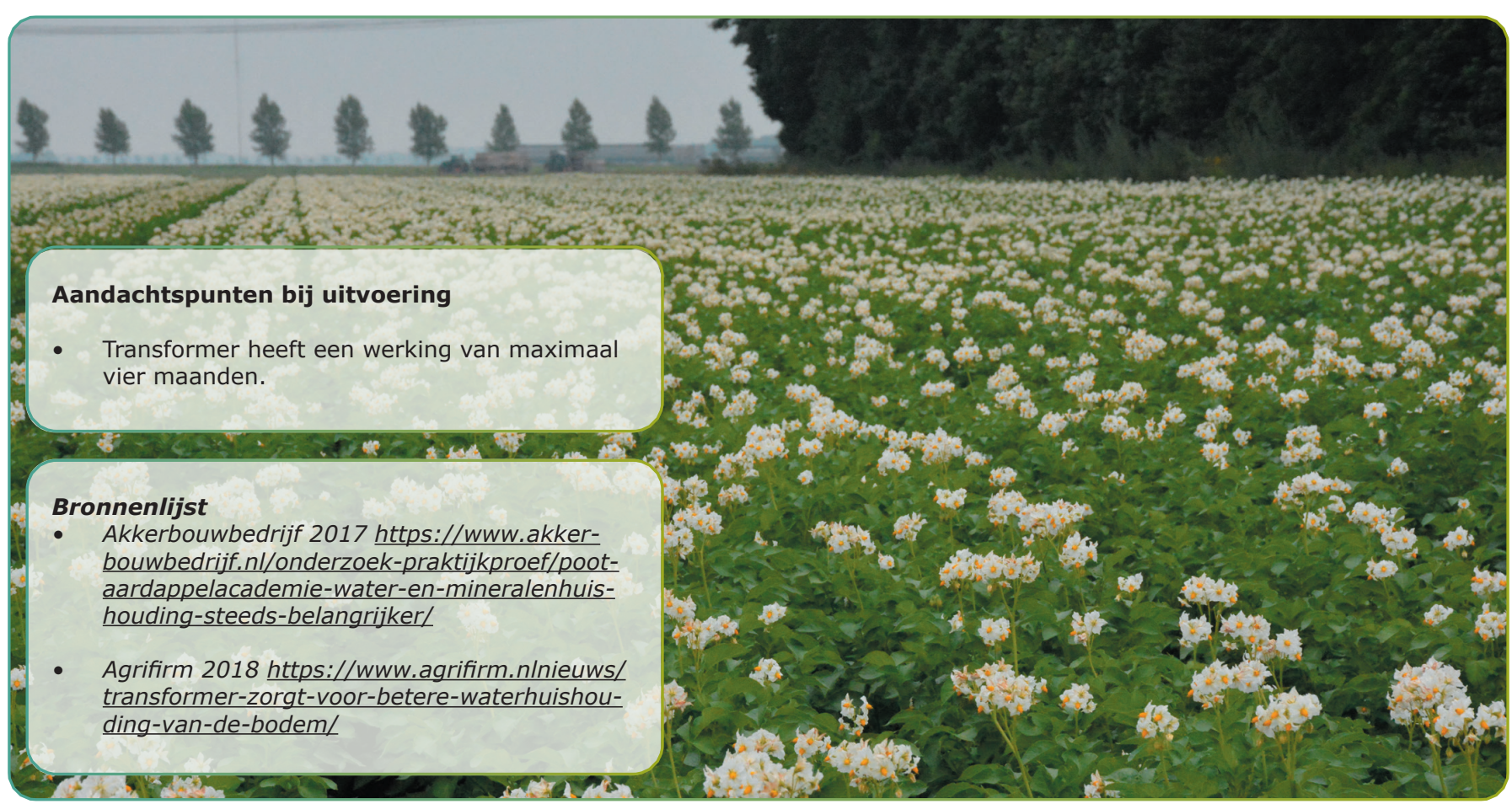




\section{$4 \quad$ Conclusie}

Klimaatverandering beïnvloed de akkerbouw en dat effect zal in de toekomst prominenter worden. Dat verschilt wel per akkerbouwgebied in Nederland en per gewas en bedrijfstype. Aan de kust speelt met name verzilting, terwijl in het binnenland hittegolven vaker voor gaan komen. In lijn met de vier klimaattrends, zijn in dit rapport tevens per maand de verwachte klimaatveranderingen in termen van temperatuurverandering en neerslagverschillen uitgewerkt voor het klimaat rond 2050. Deze bieden input voor de risico's op gewasniveau per regio en geeft ook de noodzaak aan voor doelgerichte adaptatie.

Uit het literatuuronderzoek aangevuld met expertkennis naar kwetsbaarheden per gewas komt naar voren dat sommige risico's van kwetsbaarheden toenemen en andere juist afnemen. De stijging van de temperatuur in de klimaatscenario's verlengen het groeiseizoen en zorgen voor minder risico rondom het doodvriezen van gewassen. Tegelijkertijd zorgen deze klimaatfactoren er ook voor dat de ziekte en plagendruk kan toenemen doordat de omstandigheden om te overwinteren gunstiger worden, resulterend in bijvoorbeeld aardappelopslag of het overwinteren van poppen. Een toename van de hoeveelheid neerslag kan zorgen dat het aantal gunstige momenten om de grondbewerking uit

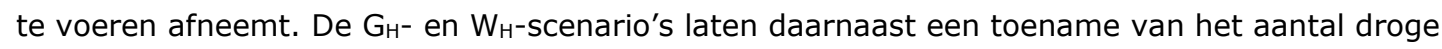
periodes zien met een afnemende neerslag in de zomer. Dit kan naast een achterblijvende fotosynthese ervoor zorgen dat er problemen ontstaan zoals doorwas (bij aardappel) en Valse meeldauw (zaaiui). Wanneer tijdens de oogstperiode de hoeveelheid neerslag toeneemt kan het risico op bodemverdichting toenemen. Hoe dit precies uitpakt is mede afhankelijk van het gewas, een gewas als wintertarwe kan mogelijk eerder worden geoogst omdat eerder aan de temperatuursom wordt voldaan. Voor verzilting zijn ook verschillen gevonden. Suikerbieten en granen kunnen beter tegen ziltere omstandigheden dan aardappel, ui en peen. Dat geldt tevens voor beregenen met verzilt water. Bij een ernstige droogte, kan het beregenen met licht verzilt water de schade van de droogte echter verminderen.

De factsheets tonen de effectiviteit en toepasbaarheid van klimaatadaptatiemaatregelen voor de akkerbouw. De meeste maatregelen zijn effectief op het bufferen van de negatieve effecten van de klimaattrends het wordt droger en het wordt natter. Dat komt omdat de maatregelen gericht zijn op het verbeteren van bodem en waterbeheer, en daarmee de teelt van de gewassen weerbaarder maken. De factsheets kunnen gebruikt worden door akkerbouwers die in de praktijk aan de slag willen met klimaatadaptatie. 


\section{Literatuur}

Aulakh, M. S., Doran, J. W., \& Mosier, A. R. (1992). Soil Denitrification-Significance, Measurement, and Effects of Management (pp. 1-57). Springer, New York, NY. https://doi.org/10.1007/978-1-46122844-8_1

Bergant, K., Trdan, S., Žnidarčič, D., Črepinšek, Z., \& Kajfež-Bogataj, L. (2005). Impact of Climate Change on Developmental Dynamics of Thrips tabaci (Thysanoptera: Thripidae): Can It Be Quantified? Environmental Entomology, 34(4), 755-766. https://doi.org/10.1603/0046-225X-34.4.755

Bijker, W., \& Verstand, D. (2020). Toepassing klimaatstresstest open teelten. Wageningen.

Bodlaender, K. B. A., Lugt, C., \& Marinus, J. (1964). The induction of second-growth in potato tubers. European Potato Journal, 7(1), 57-71. https://doi.org/10.1007/BF02366307

Boerderij. (2018). Beregeningsverbod 2018: waar mag je niet beregenen? Retrieved February 10, 2020, from https://www.boerderij.nl/Home/Nieuws/2018/7/Hier-mag-beregenen-met-oppervlaktewater-niet309212E/

Braam, G. (2018). Wat te doen tegen verzilting 2018. STOWA, Delphy.

Buishand, T. (1981). Teelt van winterpeen.

Bus, C. B., Van Loon, C. D., \& Veerman, A. (2003). Teelt van pootaardappelen. Wageningen: Praktijkonderzoek Plant \& Omgeving B.V.

CBS. (2019). CBS landbouwtellingen. Retrieved from https://opendata.cbs.nl/\#/CBS/nl/

Coakley, S. M., Scherm, H., \& Chakraborty, S. (1999). CLIMATE CHANGE AND PLANT DISEASE MANAGEMENT.

Darwinkel, A. (1997). Teelthandleiding wintertarwe.

De Visser, C. L. M., \& Zwanepol, S. (1993). Teelt van zaaiuien.

Dean, G. J. (1974). The overwintering and abundance of cereal aphids. Annals of Applied Biology, 76(1), 17. https://doi.org/10.1111/j.1744-7348.1974.tb01351.x

Geijzendorffer, I., Smidt, R., Engelbertink, R., Hermans, T., Schaap, B., Verhagen, J., \& Blom-Zandstra, G. (2011). Gevolgen van klimaatextremen voor de Nederlandse landbouw.

Groen Kennisnet. (2019). Echte meeldauw - algemeen.

Groenkennisnet. (2016). Wortelvlieg.

Haverkort, A. J., Struik, P. C., Visser, R. G. F., \& Jacobsen, E. (2009). Applied Biotechnology to Combat Late Blight in Potato Caused by Phytophthora Infestans. Potato Research, 52(3), 249-264. https://doi.org/10.1007/s11540-009-9136-3

Haverkort, A. J., \& Verhagen, A. (2008). Climate change and its repercussions for the potato supply chain. In Potato Research (Vol. 51, pp. 223-237). Springer. https://doi.org/10.1007/s11540-008-9107-0

IRS. (2020). Complete Teelthandleiding.

Juroszek, P., \& von Tiedemann, A. (2013, December). Climate change and potential future risks through wheat diseases: A review. European Journal of Plant Pathology. Springer. https://doi.org/10.1007/s10658-012-0144-9

Klein Tank, A., Beersma, J., Bessembinder, J., Van den Hurk, B., \& Lenderink, G. (2014). KNMI '14 klimaatscenario's voor Nederland. De Bilt.

Klimaateffectatlas. (2020). Kaarten over klimaateffecten. Retrieved from https://www.klimaateffectatlas.nl/nl/

KNMI. (2020). Vaker droger in het binnenland.

Manderscheid, R., \& Weigel, H. J. (2007). Drought stress effects on wheat are mitigated by atmospheric $\mathrm{CO} 2$ enrichment. Agronomy for Sustainable Development, 27(2), 79-87. https://doi.org/10.1051/agro:2006035

Ministerie van LNV. (2020). Actieprogramma klimaatadaptatie landbouw.

NAS. (2019). NAS adaptatietool. Retrieved from https://nas-adaptatietool.nl/

NVWA. (n.d.). Beregeningsverboden consumptieaardappelen, zetmeelaardappelen en tomaten | Plantenziekten en plagen | NVWA.

Oude Essink, G. H. P., \& Van Baaren, E. S. (2009). Verzilting van het Nederlandse grondwatersysteem.

Parikka, P., Hakala, K., \& Tiilikkala, K. (2012). Expected shifts in Fusarium species' composition on cereal grain in Northern Europe due to climatic change. Food Additives and Contaminants - Part A Chemistry, Analysis, Control, Exposure and Risk Assessment, 29(10), 1543-1555. https://doi.org/10.1080/19440049.2012.680613

PBL. (2012). Effecten van klimaatverandering in Nederland : 2012. Retrieved from http://www.knmi.nl/bibliotheek/klimaatrapporten/Effecten_van_klimaatverandering_in_Nederland_201 


\section{2.pdf}

Polman, N., Linderhof, V., Michels, R., van der Sandt, K., \& Vogelzang, T. (2012). Landbouw in een veranderende delta - Toekomstscenario's voor zoetwatergebruik.

Porter, J. H., Parry, M. L., \& Carter, T. R. (1991). The potential effects of climatic change on agricultural insect pests. Agricultural and Forest Meteorology, 57(1-3), 221-240. https://doi.org/10.1016/01681923(91)90088-8

Powell, J. P., \& Reinhard, S. (2016). Measuring the effects of extreme weather events on yields. Weather and Climate Extremes, 12, 69-79. https://doi.org/10.1016/J.WACE.2016.02.003

Prins, P. (2011). Boeren op weg naar klimaatbestendige productie.

Roest, C. W. J., Bakel, P. van, \& Smit, A. A. M. F. R. (2003). Actualisering van de zouttolerantie van land-en tuinbouwgewassen ten behoeve van de berekening van de zoutschade in Nederland met het RIZAinstrumentarium. Retrieved from http://www.helpdeskwater.nl/publish/pages/15603/04zouttolerantie_landbouw.pdf

Schaap, B. F., Blom-Zandstra, M., Hermans, C. M. L., Meerburg, B. G., \& Verhagen, J. (2011). Impact changes of climatic extremes on arable farming in the north of the Netherlands. Regional Environmental Change, 11(3), 731-741. https://doi.org/10.1007/s10113-011-0205-1

Schapendonk, A. H. C. M., Pot, C. S., \& Goudriaan, J. (1995). Simulated effects of elevated carbon dioxide concentration and temperature on the productivity of potato (pp. 101-113). Springer, Dordrecht. https://doi.org/10.1007/978-94-011-0051-9_7

Smit, B., \& Jager, J. (2018). Schets van de akkerbouw in Nederland: milieukenmerken die een relatie hebben tot biodiversiteit.

Spaarwater. (2019). Rendabel en duurzaam agrarisch watergebruik en waterbeheer in de verziltende Waddenregio.

Stokkers, R., Prins, H., Meer, R. van der, \& Jager, J. (2018). Effecten droogte en hitte op inkomens land-en tuinbouw: Update begin oktober.

STOWA. (2019). Een actueel beeld van de kans op extreme neerslag.

Stuyt, L. C. P. M., Blom-Zandstra, M., \& Kselik, R. A. L. (2016). Inventarisatie en analyse zouttolerantie van landbouwgewassen op basis van bestaande gegevens. Wageningen Environmental Research (Vol. 2739).

Sukkel, W., Van Leeuwen-Haagsma, W. K., Van Balen, D. J. M., \& Holwerda, J. (2004). Zeven teelten in praktijk Teelthandleidingen voor biologisch geteelde gewassen.

Toth, I. K., van der Wolf, J. M., Saddler, G., Lojkowska, E., Hélias, V., Pirhonen, M., ... Elphinstone, J. G. (2011). Dickeya species: an emerging problem for potato production in Europe. Plant Pathology, 60(3), 385-399. https://doi.org/10.1111/j.1365-3059.2011.02427.x

van Bakel, P. J. T., Blom-Zandstra, M., \& Stuyt, L. C. P. . (2018). Zouttolerantie van gewassen afhankelijk van het groeistadium?

Van Bakel, P. J. T., Kselik, R. a L., Roest, C. W. J., \& Smit, a a M. F. R. (2009). Review of crop salt tolerance in the Netherlands. Alterra rapport 1926. Retrieved from http://library.wur.nl/WebQuery/clc/2003051

Van den Broek, R. C. F. M. (2003). Teelthandleiding zaaiuien.

van Hussen, K., van de Velde, I., Läkamp, R., \& van der Kooij, S. (2019). Economische schade door droogte in 2018.

Van Loon, C. D. (1981). The effect of water stress on potato growth, development, and yield. American Potato Journal, 58(1), 51-69. https://doi.org/10.1007/BF02855380

Van Loon, C. D., \& Veerman, A. (1993). Teelt van consumptieaardappelen.

Van Oort, P. A. J., Timmermans, B. G. H., Meinke, H., \& Van Ittersum, M. K. (2012). Key weather extremes affecting potato production in The Netherlands. European Journal of Agronomy, 37(1), 11-22. https://doi.org/10.1016/J.EJA.2011.09.002

Vandenbossche, B. A. B., Niere, B., \& Vidal, S. (2015). Effect of temperature on the hatch of two german populations of the beet cyst nematodes, heterodera schachtii and heterodera betae. Journal of Plant Diseases and Protection, 122(5-6), 250-254. https://doi.org/10.1007/BF03356560

Veerman, A. (2003). Teelt van consumptieaardappelen. Lelystad: Praktijkonderzoek Plant \& Omgeving.

Verstand, D. (2021). Maatregelen Factsheets Klimaatadaptatie Open Teelten. Wageningen. Retrieved from https://edepot.wur.nl/556356

Verstand, Daan, Schaap, B., Schoorlemmer, H., Wolf, P. De, van Balen, D., \& Verhagen, J. (2020). Klimaatadaptatie in de open teelten. Wageningen.

Westerdijk, C., Zwanepol, S., Heijbroek, W., \& Houtman, H. (1994). Teelt van suikerbieten.

Wit de, J., Swart, D., \& Luijendijk, E. (2009). Klimaat en landbouw Noord- Nederland: ' effecten van extremen ', 112.

Wösten, J. H. M., Veerman, G. J., de Groot, W. J. M., \& Stolte, J. (2001). Waterretentie- en doorlatendheidskarakteristieken van boven- en ondergronden in Nederland: de Staringreeks. Retrieved from https://edepot.wur.nl/512761

Wurr, D. C. E., Hand, D. W., Edmondson, R. N., Fellows, J. R., Hannah, M. A., \& Cribb, D. M. (1998). Climate 
change: A response surface study of the effects of $\mathrm{CO} 2$ and temperature on the growth of beetroot, carrots and onions. Journal of Agricultural Science, 131(2), 125-133.

https://doi.org/10.1017/S0021859698005681

Yamamura, K., \& Kiritani, K. (1998). A simple method to estimate the potential increase in the number of generations under global warming in temperate zones. Applied Entomology and Zoology, 33(2), 289298. https://doi.org/10.1303/aez.33.289 
Correspondentie adres voor dit rapport: Postbus 16

6700 AA Wageningen

T 0317480700

www.wur.nl/plant-research

Rapport WPR-902
De missie van Wageningen University \& Research is 'To explore the potential of nature to improve the quality of life'. Binnen Wageningen University \& Research bundelen Wageningen University en gespecialiseerde onderzoeksinstituten van Stichting Wageningen Research hun krachten om bij te dragen aan de oplossing van belangrijke vragen in het domein van gezonde voeding en leefomgeving. Met ongeveer 30 vestigingen, 5.000 medewerkers en 12.000 studenten behoort Wageningen University \& Research wereldwijd tot de aansprekende kennisinstellingen binnen haar domein. De integrale benadering van de vraagstukken en de samenwerking tussen verschillende disciplines vormen het hart van de unieke Wageningen aanpak. 


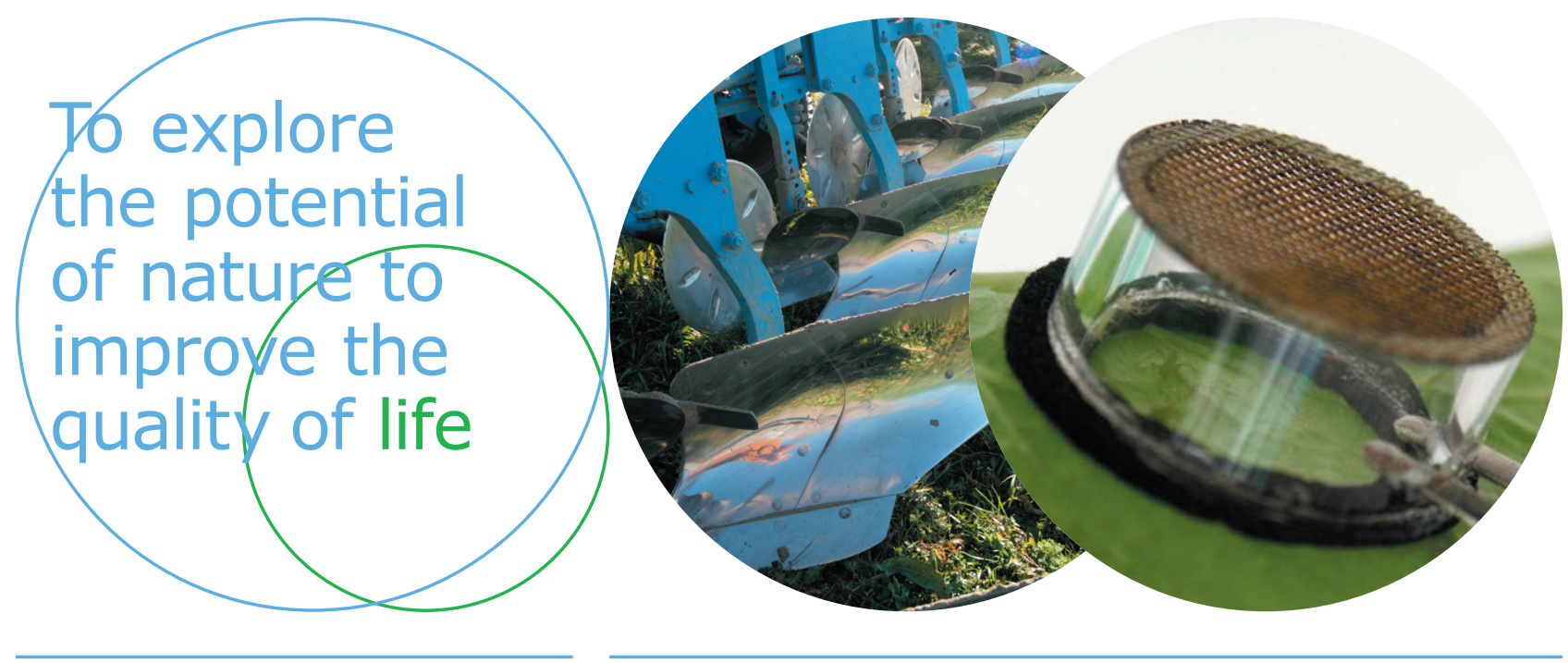

Wageningen University \& Research

\section{Open Teelten}

Edelhertweg 1

Postbus 430

8200 AK Lelystad

T (+31)320 291111

www.wur.nl/openteelten

Rapport WPR-902
De missie van Wageningen University \& Research is 'To explore the potential of nature to improve the quality of life'. Binnen Wageningen University \& Research bundelen 9 gespecialiseerde onderzoeksinstituten van stichting DLO en Wageningen University hun krachten om bij te dragen aan de oplossing van belangrijke vragen in het domein van gezonde voeding en leefomgeving. Met ongeveer 30 vestigingen, 6.500 medewerkers en 12.500 studenten behoort Wageningen University \& Research wereldwijd tot de aansprekende kennisinstellingen binnen haar domein. De integrale benadering van de vraagstukken en de samenwerking tussen verschillende disciplines vormen het hart van de unieke Wageningen aanpak. 